\title{
АПРОБАЦИЯ МЕТОДИК ПРОГНОЗИРОВАНИЯ ТЕХНОЛОГИЧЕСКОЙ ЭФФЕКТИВНОСТИ ВЫРАБОТКИ И ОЦЕНКИ ЗАПАСОВ НЕФТИ ПРИ ПОДБОРЕ СКВАЖИН-КАНДИДАТОВ НА ПРОВЕДЕНИЕ МЕРОПРИЯТИЙ ПО ОБРАБОТКЕ ПРИЗАБОЙНОЙ ЗОНЫ СКВАЖИН НА ПРИМЕРЕ СЕВЕРО-ОРЕХОВСКОГО МЕСТОРОЖДЕНИЯ
}

\author{
Дягилев Валерий Федорович', \\ glibazval.dyagilev@yandex.ru \\ Институт геологии и нефтегазодобычи Тюменского индустриального университета, \\ Россия, 625000, г. Тюмень, ул. Володарского, 38.
}

\begin{abstract}
Актуальность исследования вызвана необходимостью оценки текущего состояния качества запасов нефти призабойной зоны скважин и прогнозирования технологической эффективности существующей выработки нефтяных запасов при подборе скважин-кандидатов на проведение мероприятий по обработке призабойной зоны, что соответствует потребностям мировой практики в поиске наиболее результативных методик освоения нефтегазовых месторождений.

Цель: определить величину изменения балансовых запасов нефти на примере Северо-Ореховского месторождения и произвести анализ методик, позволяющих осуществить прогнозирование технологической эффективности выработки и оценки запасов нефти при подборе скважин-кандидатов на проведение мероприятий по обработке призабойной зоны скважин, применяемых на территории Северо-Ореховского месторождения
\end{abstract}

Объект: Северо-Ореховское месторождение как энергоресурсный комплекс, на базе которого осуществляется не только применение традиционных методик прогнозирования технологической эффективности выработки нефтяных запасов, но и апробируется качественно новая методика оценки запасов нефти при подборе скважин-кандидатов на проведение мероприятий по обработке призабойной зоны.

Методы: прогнозирование, обусловившее понимание технологической эффективности выработки и оценки запасов нефти при подборе скважин-кандидатов на проведение мероприятий по обработке призабойной зоны скважин; определение величин удельных остаточных балансовых запасов обусловило обращение к сравнительному анализу возможностей Скважин доноров и акцепторов; анализ и оценка величины выходящих из дренирования запасов; оценка значения текущей нефтенасыщенности.

Результаты. Большинство нефтяных месторождений Западной Сибири находится на поздней стадии разработки. В связи с этим вопрос выработки остаточных запасов становится первоочередным. Для принятия проектных решений на прогнозный период разработки необходима оценка остаточных ресурсов углеводородов месторождения, что обусловливает актуальность исследования и адаптации методов оценки ресурсов месторождения. Произведен сравнительный анализ существующих методик прогнозирования технологической эффективности выработки и оценки запасов нефти, используемых при подборе скважин-кандидатов на проведение мероприятий по обработке призабойной зоны скважин. Предлагается измененный способ определения удельных балансовых запасов нефти, позволяющий для каждой добывающей скважины учесть запасы и отборы всего объекта, а также фильтрационно-емкостные свойства всего фонда скважин. Установлено, что метод определения величин удельных остаточных балансовых запасов предполагает выявление скважин доноров и акцепторов. Выявлено, что используемый подход в подборе скважин-кандидатов под обработку призабойной зоны является универсальным, так как позволяет выявлять скважины с недостаточной выработкой при существующем потенциале (водоограничивающие, гидрофобизирующие методы увеличения нефтеотдачи). Более того, данный методический подход предполагает принцип оценки относительной динамики отборов нефти и выявление несоотносимо высоких с остаточным потенциалом темпов падения добычи нефти.

Методический подход, совмещающий свойства прогноза ожидаемой технологической эффективности и критериального обоснования, основывается на применении процедуры расчетов параметров множественного регрессионного анализа. В его основе лежит предположение, что технологическая эффективность мероприятий (исключая успешность, случайный фактор) тесно связана с геолого-технологическими параметрами, характеризующими потенциал скважин - остаточные извлекаемые запасы, эффективная нефтенасыщенная мощность, площадь зоны дренирования, проницаемость и т. Д. Доказывается, что данный метод подходит не только для подбора скважин-кандидатов под обработку призабойной зоны, но и для групп технологий увеличения нефтеотдачи различной специфики (по механизму вовлечения незадействованных запасов нефти); искомой функцией является технологическая эффективность от мероприятий (за год или за месяц), а аргументами - набор геолого-технологических показателей фонда скважин на дату проведения мероприятия.

Предложена методика оценки остаточных балансовых запасов фонда скважин, что способствует определению качества нефтяных запасов для отдельной добывающей скважины и позволяет учесть запасы и отборы всего объекта, а также фильтрационноемкостные свойства всего фонда скважин.

Выводы. Установлено, что выявленные в ходе анализа особенности существующих методик позволяют решить ряд нефтепромысловых задач: определить объем выходящих из дренирования запасов (подбор водоограничивающих методов увеличения нефтеотдачи, ремонтно-изоляционные работы, коррекция режимов работы скважин, остановки); определить величину незадействованных запасов нефти, не участвующих в дренировании (гидровлический разрыв пласта, уплотнение); проанализировать достижимость выработки извлекаемых запасов, оцениваемых по общепринятым характеристикам вытеснения, по добывающим скважинам, то есть произвести их коррекцию.

\section{Ключевые слова:}

Призабойные зоны скважин, методика определения остаточных балансовых запасов фонда скважин, методика прогнозирования технологической эффективности выработки и оценки запасов нефти, Северо-Ореховское месторождение. 


\section{Введение}

Наблюдающийся в настоящее время интерес мирового научного сообщества к поиску универсального метода, позволяющего осуществлять эффективное использование углеводородных ресурсов [1, 2 и др.], вызывает потребность исследования методик прогнозирования технологической эффективности выработки и оценки запасов нефти. Анализ современной методологии разработки природных ресурсов нефтегазовых комплексов [3, 4 и др.] показал своевременность исследования существующих приемов и принципов оценки текущего состояния нефтяных запасов северных территорий РФ. Обращение к переоценке существующих методов прогнозирования добычи запасов нефти [5, 6 и др.], а также создание новейших методик прогнозирования технологической эффективности выработки и оценки запасов нефти представляются актуальными. Более того, назрела необходимость создания условий по их внедрению в практике использования на подборе скважинкандидатов на проведение мероприятий по обработке призабойной зоны скважин.

\section{О методике определения остаточных \\ балансовых запасов фонда скважин}

В процессе разработки нефтяных месторождений ряд эксплуатационных скважин характеризуется превышением суммарных отборов нефти своих удельных балансовых запасов (геологических), определяемых по геометрическим границам (области Вороного) [7, 8]. При этом выработка удельных балансовых запасов может достигать $500 \%$ и более. То есть справедливо утверждение, описанное неравенством (1)

$$
\Sigma Q_{\text {н }}>Q_{\text {бал.н }}, \text { при } Q_{\text {бал.н }}=S_{\text {скв }} h_{\text {э.н. }} m K_{\text {н }} \rho_{\text {н }} \theta,
$$

где $Q_{\text {бал }}-$ удельные балансовые запасы; $S_{\text {скв }}$ - площадь дренирования запасов скважин; $h_{\text {эф.н }}-$ эффективная нефтенасыщенная мощность; $m$ - пористость; $K_{\text {н }}$ - начальная нефтенасыщенность; $\rho_{\text {н }}$ плотность нефти в пластовых условиях; $\theta$ - пересчетный коэффициент.

Причинами данной особенности добывающих скважин могут быть:

1) неравномерность ввода скважин в разработку, когда более ранние по вводу добывающие скважины в процессе эксплуатации успевают «захватить» запасы зон дренирования соседних скважин;

2) вытеснение нефти водой, когда вытесняемая водой нефть движется к участкам с хорошими фильтрационно-емкостными свойствами, аккумулирующим подток вытесняемой нефти;

3) природный характер строения коллектора и распределение естественного пластового давления в залежи.

Отмеченные особенности свидетельствуют о наличии единых гидродинамических систем в пределах объектов разработки [9], влиянии работы одних скважин на работу многих других, наличии перетоков нефти из одной области в другую. В этой связи предлагается измененный способ определения удельных балансовых запасов нефти, позволяющий для каждой добывающей скважины учесть запасы и отборы всего объекта, а также фильтрационно-емкостные свойства всего фонда скважин. Удельные балансовые запасы предлагается определять по формуле (2)

$$
\begin{aligned}
& Q_{\text {геол. }}^{\text {факт }}=\left[\left(\frac{Q_{\text {геол.н }}-\sum_{1}^{t-1} \sum_{1}^{n} Q_{\mathrm{H}}}{\sum_{1}^{t} N_{\text {скв }}}\right) K_{i}+\sum_{1}^{t-1} Q_{\mathrm{Hi}}\right], \\
& K_{i}=\frac{h_{\text {эф.н }} m_{i} k_{\text {н.тек. } i} S_{\text {скв }}}{\overline{h_{\text {эф.н }}} \bar{m} \overline{k_{\text {н.тек }} S_{\text {н }}}},
\end{aligned}
$$

где

где $n$ - количество скважин по объекту (залежи), пробуренных на время $t-1 ; \sum_{1}^{t-1} \sum_{1}^{n} Q_{\mathrm{H}}-$ суммарный отбор нефти по объекту к моменту времени $t-1$; $K_{i}$ - коэффициент приведения подсчетных параметров к условиям $i$-й скважины; $S_{\text {н }}$ - горизонтальная проекция площади залежей нефти на подсчетном участке; $\sum_{1}^{t-1} Q_{\text {ні }}$ - накопленный отбор нефти по скважине к моменту времени $t-1$.

В случае если величина удельных фактических геологических запасов рассчитывается по перфорированной толщине, величина $k_{\text {н.те.. }}$ к моменту $t$ определяется исходя из удельных запасов и накопленных отборов предыдущего момента времени $t-1$, а также подсчетных параметров скважины. Если величина удельных фактических геологических запасов рассчитывается в целом по пласту, значение $k_{\text {нгек. }}$ на время $t-1$ определяется как средневзвешенное по мощности по перфорированным и неперфорированным участкам пласта. Расчет может производиться и исключительно по перфорированным мощностям.

Величина остаточных балансовых запасов нефти будет определяться как разница между удельными балансовыми запасами и накопленной добычей нефти по скважине на текущий момент времени $t$ по формуле (3)

$$
Q_{\text {н.ост. } i}^{t}=Q_{\text {геол. } i}^{\text {факт }}-\sum^{t} Q_{\text {н } i} .
$$

Разность между удельными балансовыми запасами по предложенной методике и запасами по области Вороного показывает величину изменения балансовых запасов нефти (рис. 1) в процессе эксплуатации скважины, определяемую по формуле (4)

$$
d \overline{Q_{\text {нi }}^{t}}=Q_{\text {бал.нi }}^{\text {факт.t }}-Q_{\text {бал.ні }}^{\text {геом }} .
$$

Зная величину $d Q_{\text {ні }}$ на момент времени $t$, можно определить величину $d Q_{\text {н }} / d t$, которая будет показывать дискретный объем подтока нефти (изменения запасов) по зоне дренирования. 
Нефтеотдача, д.е. (определяется через удельные запасы по геометрическим границам зон скважин)

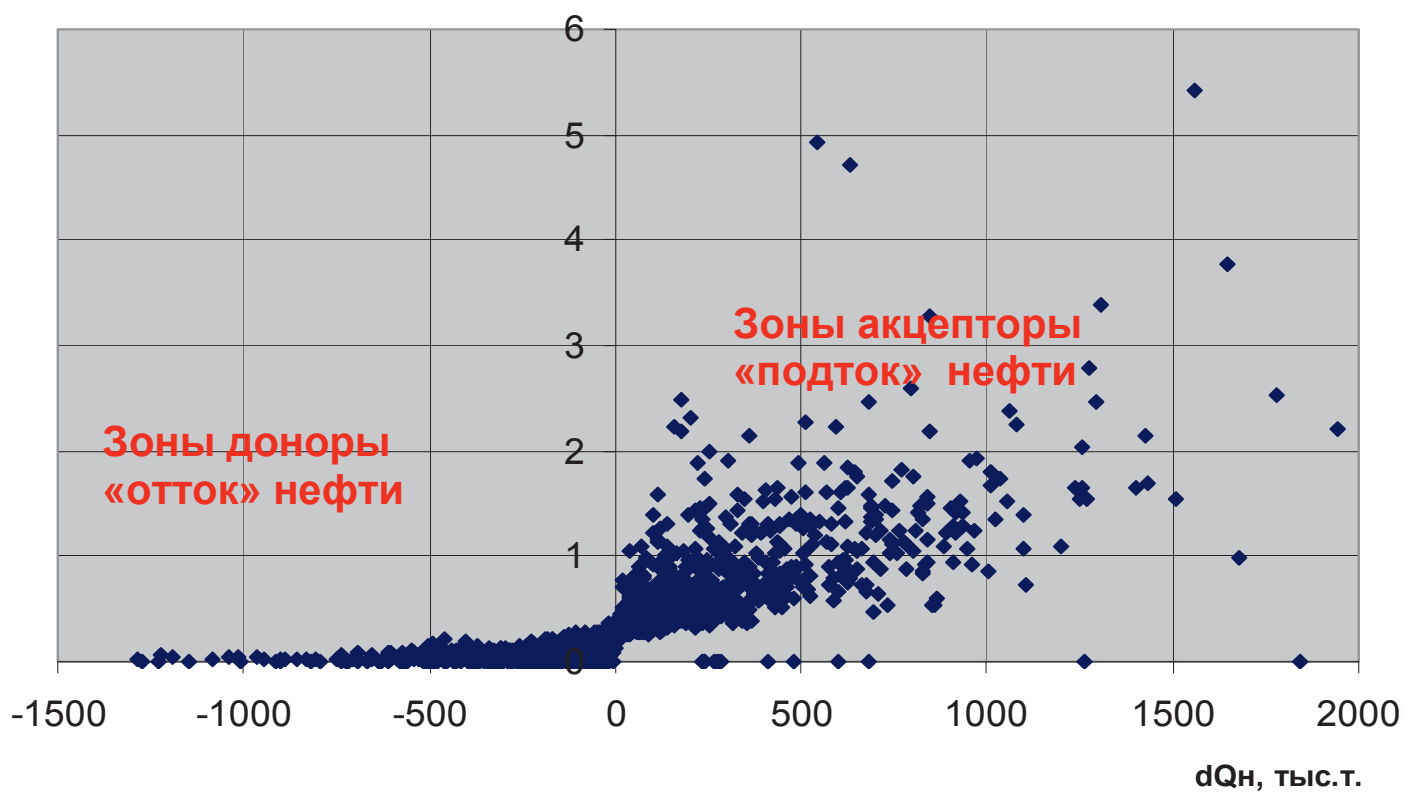

Рис. 1. Распределение фонда скважин по характеру дренирования

Fig. 1. Distribution of wells by the nature of drainage

Реализация предложенной методики определения удельных балансовых запасов по основным объектам разработки Северо-Ореховского месторождения позволила произвести их пересчет, выявить потенциальные скважины, контролирующие подток нефти, - акцепторы, а также скважины доноры, отдающие свои запасы из-за влияния системы разработки.

Учитывая наличие зон акцепторов с положительным $d Q_{\text {н }}$ и зон доноров с отрицательным $d Q_{\text {н }}$, характер подтока $d Q_{\text {н }} / d t$, несмотря на положительные значения отборов нефти, может быть отрицательным по зоне дренирования, т. е. зона скважины отдает нефть как в процессе отбора, так и в процессе перетока в смежные зоны.

Для зон акцепторов, аккумулирующих дополнительный подток нефти, текущая нефтенасыщенность всегда будет иметь повышенные значения.

Для зон доноров, имеющих «транзитное» положение относительно акцепторов и зон закачки, отдающих свои запасы, текущая нефтенасыщенность будет иметь пониженные значения.

Оценка значения текущей нефтенасыщенности, определенных по функции от доли воды и соотношения вязкостей, характеризуют состояние в зоне отбора.

Значения текущей нефтенасыщенности по доле воды и соотношению вязкостей определяется согласно данным фазовых относительных проницаемостей и уравнению Баклея-Левретта, формула (5)

$$
F_{\mathrm{B}}=1 /\left(1+\left(K_{\text {отн.н }} \mu_{\mathrm{B}} / \mu_{\mathrm{H}} K_{\text {отн.в }}\right)\right. \text {. }
$$

При отсутствии данных фазовых относительных проницаемостей по объекту текущая нефтенасыщенность определяется по диаграммам Д.А. Эфроса.
Поскольку значения нефтенасыщенности по функции от доли воды и соотношению вязкостей характеризует состояние в зоне отбора, отклонение текущей нефтенасыщенности, определяемой по соотношению вязкостей и доле воды от текущей нефтенасыщенности по предложенной методике, покажет долю незадействованных запасов в результате: прорыва языков воды, конусообразования, смещения запасов вследствие влияния смежных участков нагнетания и т. д.

Для примера на рис. 2 приведен фрагмент карты слабо дренируемых запасов окружения для нагнетательных скважин по пласту $\mathrm{A}_{2-1}$ Северо-Opeховского месторождения.

На рис. 3 представлено отображение направлений прорывов воды (по данным математического анализа влияния закачки) на карте проницаемости пласта $\mathrm{AB}_{2-1}$. Вертикальные конусы на карте отображают объем выходящих из дренирования запасов нефти.

Реализация предложенной методики определения удельных балансовых запасов по основным объектам разработки Северо-Ореховского месторождения позволила произвести их пересчет, выявить потенциальные скважины, контролирующие подток нефти, - акцепторы, а также скважины-доноры, отдающие свои запасы из-за влияния системы разработки.

Для примера на рис. 4 приведен график динамики удельных запасов по фонду скважин пласта $\mathrm{AB}_{2-1}$.

Фрагмент карты суммарных (за весь период эксплуатации) изменений удельных балансовых запасов по объекту $\mathrm{AB}_{2-1}$ представлен на рис. 5 . 


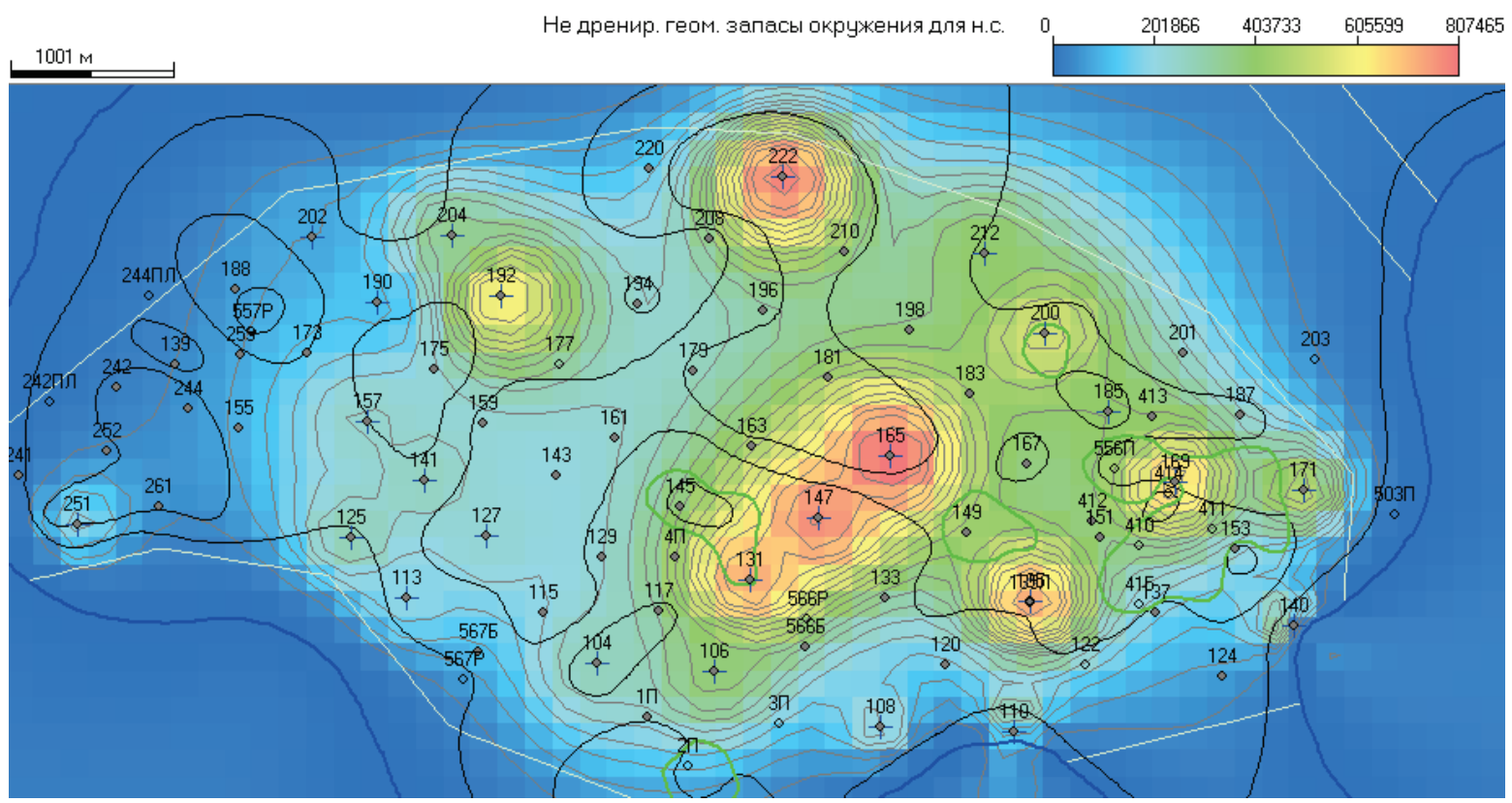

Pис. 2. Фрагмент карты слабо дренируемых запасов окружения для нагнетательных скважин по пласту $A B_{2-1}$

Fig. 2. Fragment of a map of poorly drained stockpiles in the environment for injection wells for reservoir $A V_{2-1}$

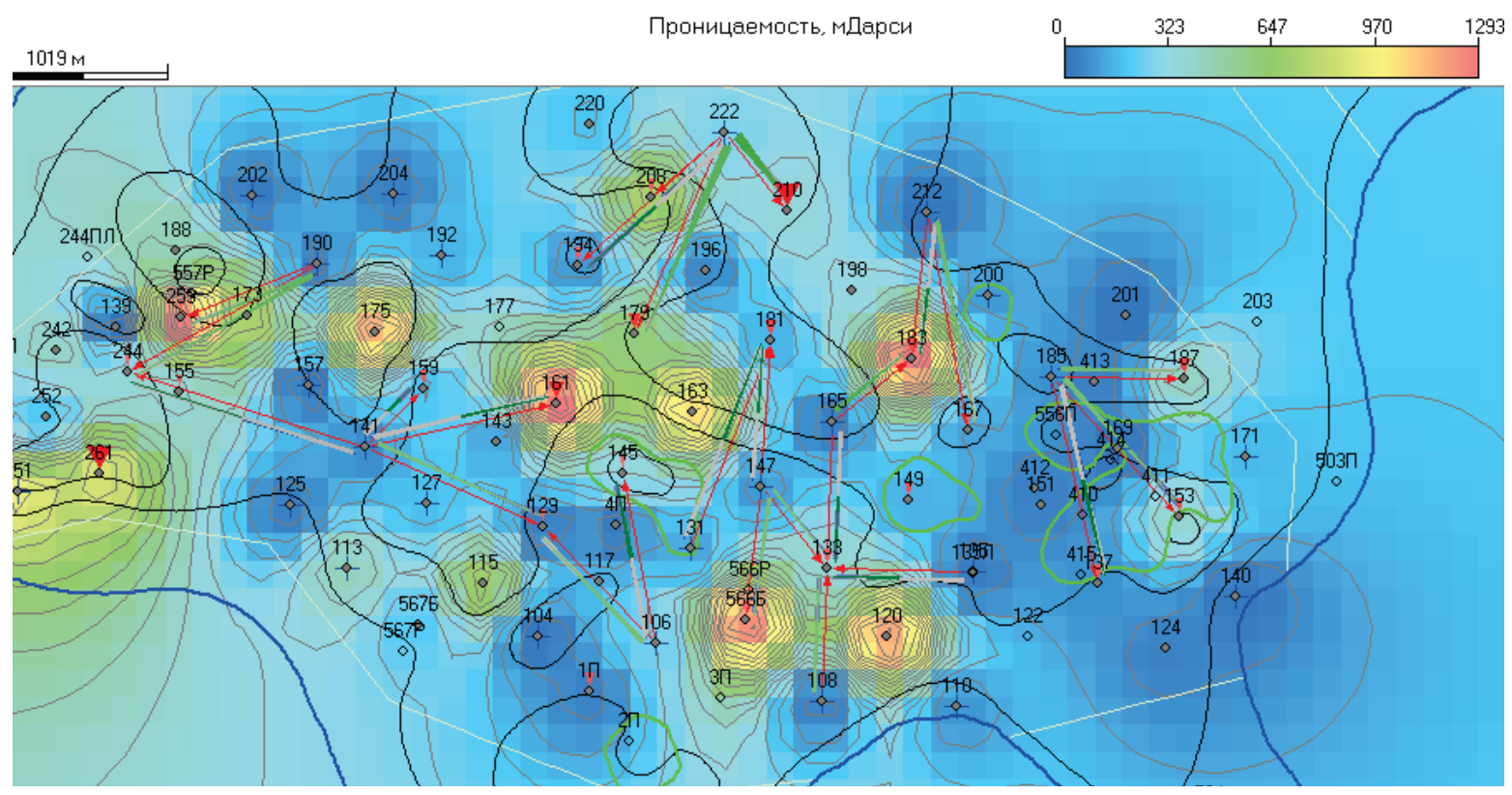

Рис. 3. Отображение направлений прорывов воды (по данным математического анализа влияния закачки) на карте проницаемости пласта $A B_{2-1}$

Fig. 3. Display of water inrush directions (by the data of mathematical analysis of injection affect) on the map of $A V_{2-1}$ reservoir permeability

По добывающим скважинам определена разница оценок текущей нефтенасыщенности, полученных по предложенной методике и по доле воды и соотношению вязкостей. Сравнение данных оценок нефтенасыщенности показывает, насколько обводненность адекватна выработке удельных запасов или насколько отличается нефтенасыщенность в зоне отбора от нефтенасыщенности по всей области влияния скважины. Кроме того, данное отличие является оценкой того объема запасов, ко- торые выходят из дренирования из-за неадекватного выработке увеличения обводненности.

На рис. 6 представлена динамика текущей нефтенасыщенности для двух групп скважин-акцепторов.

По представленным зависимостям видно, что значения текущей нефтенасыщенности по функции от воды и по методике хорошо коррелируют, кроме того, обе оценки текущей нефтенасыщенности значительно выше. В первой группе скважин 


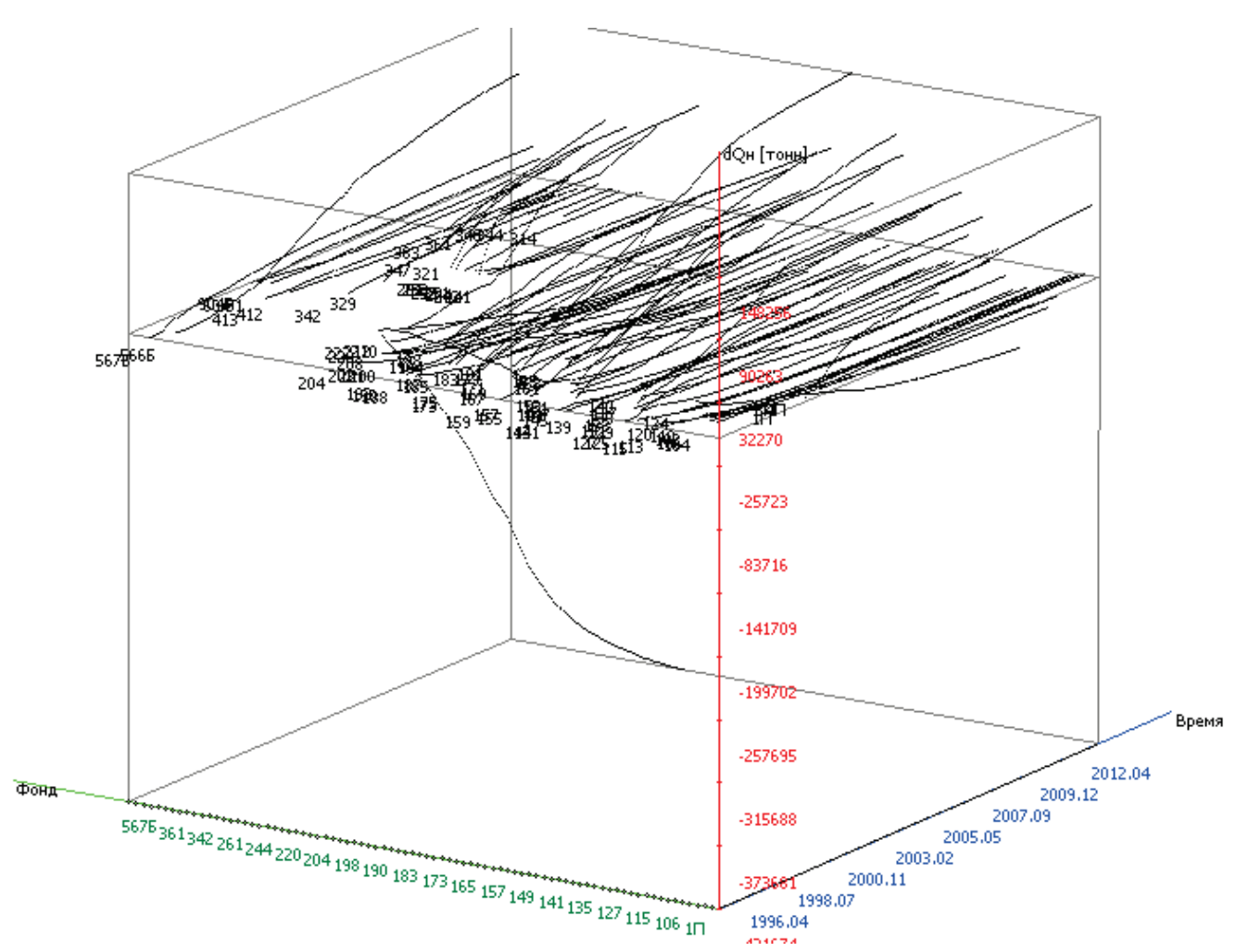

Pис. 4. Динамика изменения удельных балансовых запасов по пласту $A B_{2-1}$

Fig. 4. Dynamics of change in specific reserves by the reservoir $A V_{2-1}$

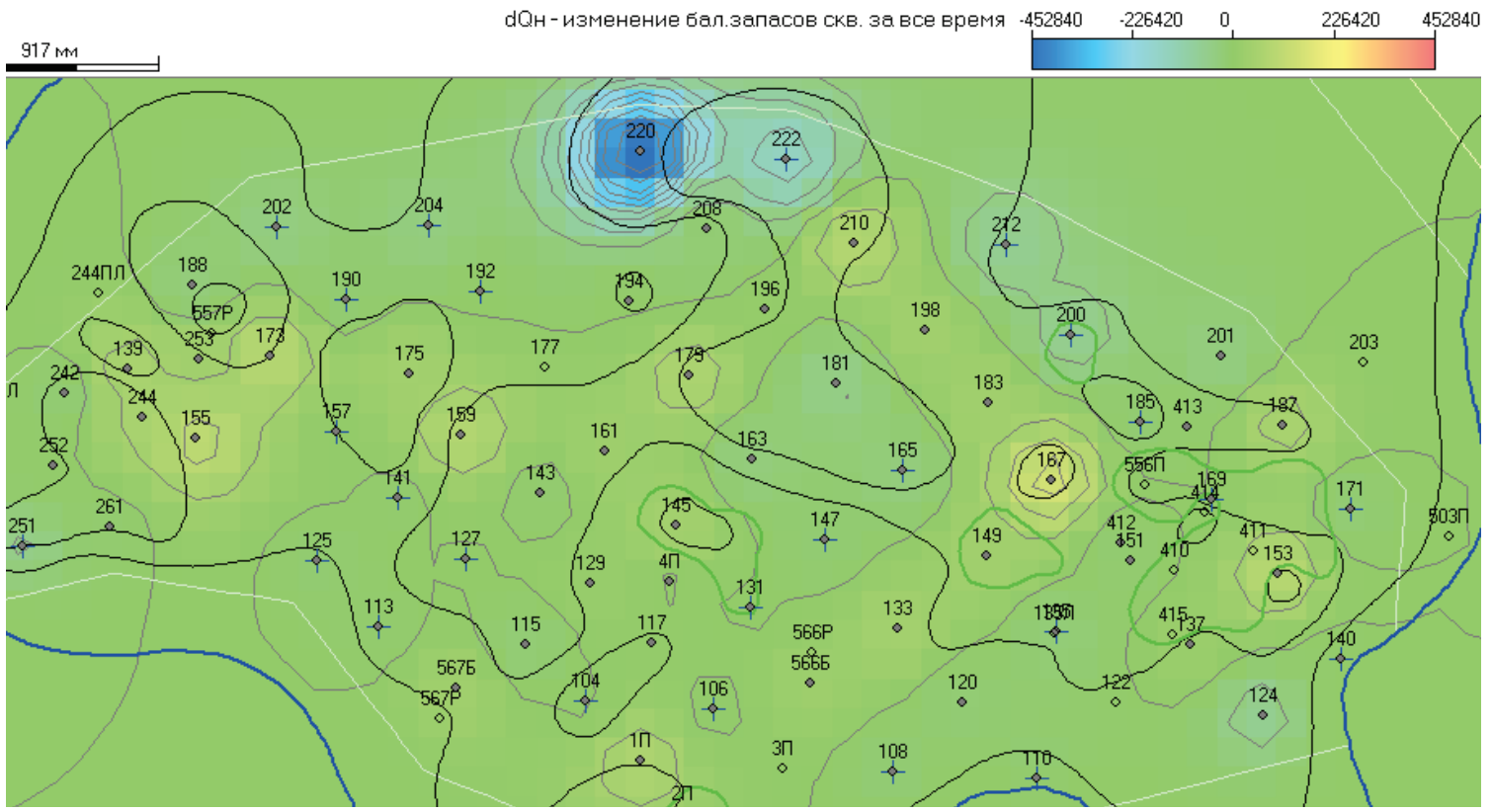

Pис. 5. Фрагмент карты изменения удельных балансовых запасов по пласту $A B_{2-1}$ по состоянию на 01.01.2014 г.

Fig. 5. Fragment of map of changes in specific reserves of reservoir $A V_{2-1}, 01.01 .2014$

(а) нефтенасыщенность по функции от воды несколько выше значений по методике, что может объясняться установлением адекватных отборов по жидкости.

В последующем моменте выработки запасов и обводнения обе оценки текущей нефтенасыщенно- сти достигают значений в 0,2 д.ед. (20\%). Во втором случае - во второй группе скважин (б) - нефтенасыщенность по функции от воды хорошо соотносится со значениями по методике, однако в заключительной стадии отмечается снижение нефтенасыщенности в зоне отбора. 

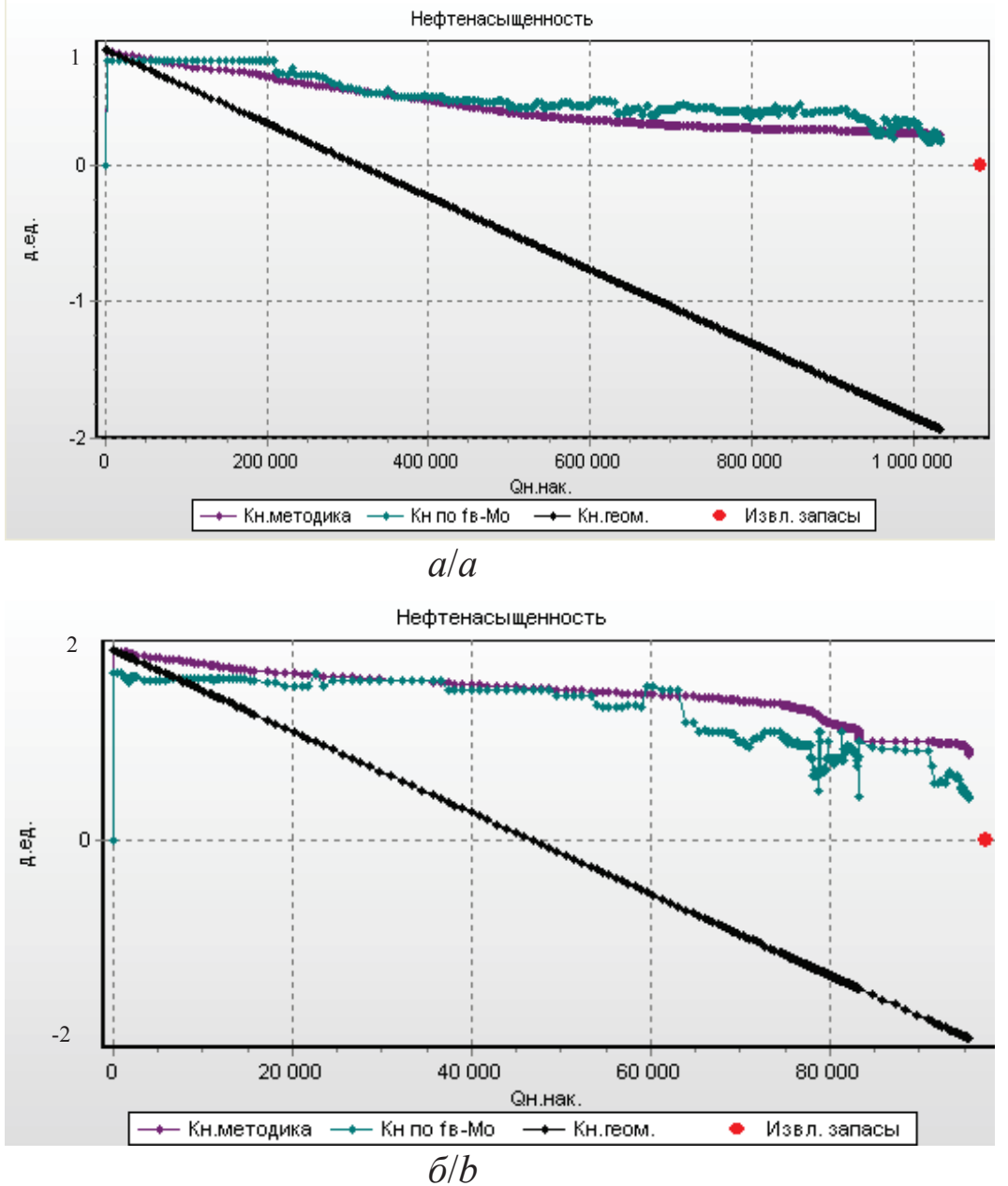

Pис.6. Диналика оценок текущей нефтенасыщенности для зон скважин-акцепторов по двум исследуемыл группал скважин: а) по первой группе скважин; б) по второй группе скважин

Fig. 6. Dynamics of estimates of the current oil saturation for the areas of wells of acceptors of two groups of wells studied: (a) the first; $b$ ) the second

На определенном этапе отмечается оптимизация отборов, что отражается в уменьшении расхождения рассматриваемых графиков.

На рис. 7 представлена динамика оценок текущей нефтенасыщенности для зон доноров. Значения текущей нефтенасыщенности по функции от воды и по методике ниже значений, определяемых по геометрическим границам скважин, соответствующим области Вороного.

На рис. 8 можно наблюдать расхождение значений оценок нефтенасыщенности по доле воды и по методике. Соотношение значений текущей нефтенасыщенности по функции от воды и по методике показывает, что зоны в пределах скважин-доноров, имеющих «транзитное» положение между нагнетательными скважинами и скважинами-акцепторами, подвержены обводнению, в большей степени несоизмеримому с выработкой запасов, и появлению $к$ моменту полного обводнения доли не вовлечённых запасов нефти.
Оценки текущей нефтенасыщенности по методике хорошо коррелируют со значениями данной оценки по функции от доли воды в начальной и средней стадии разработки. Данные оценки всегда достаточно отличаются от значений оценки текущей нефтенасыщенности по области Вороного (геометрическим границам).

Отмеченные особенности методик позволяют решить ряд нефтепромысловых задач:

- определить объем выходящих из дренирования запасов (подбор водоограничивающих МУН, РИР, коррекция режимов работы скважин, остановки);

- определить величину запасов нефти, не участвующих в дренировании (ГРП, уплотнение);

- оценить достижимость выработки извлекаемых запасов, рассчитанных по общепринятым характеристикам вытеснения, по добывающим скважинам, т. е. произвести их коррекцию. 

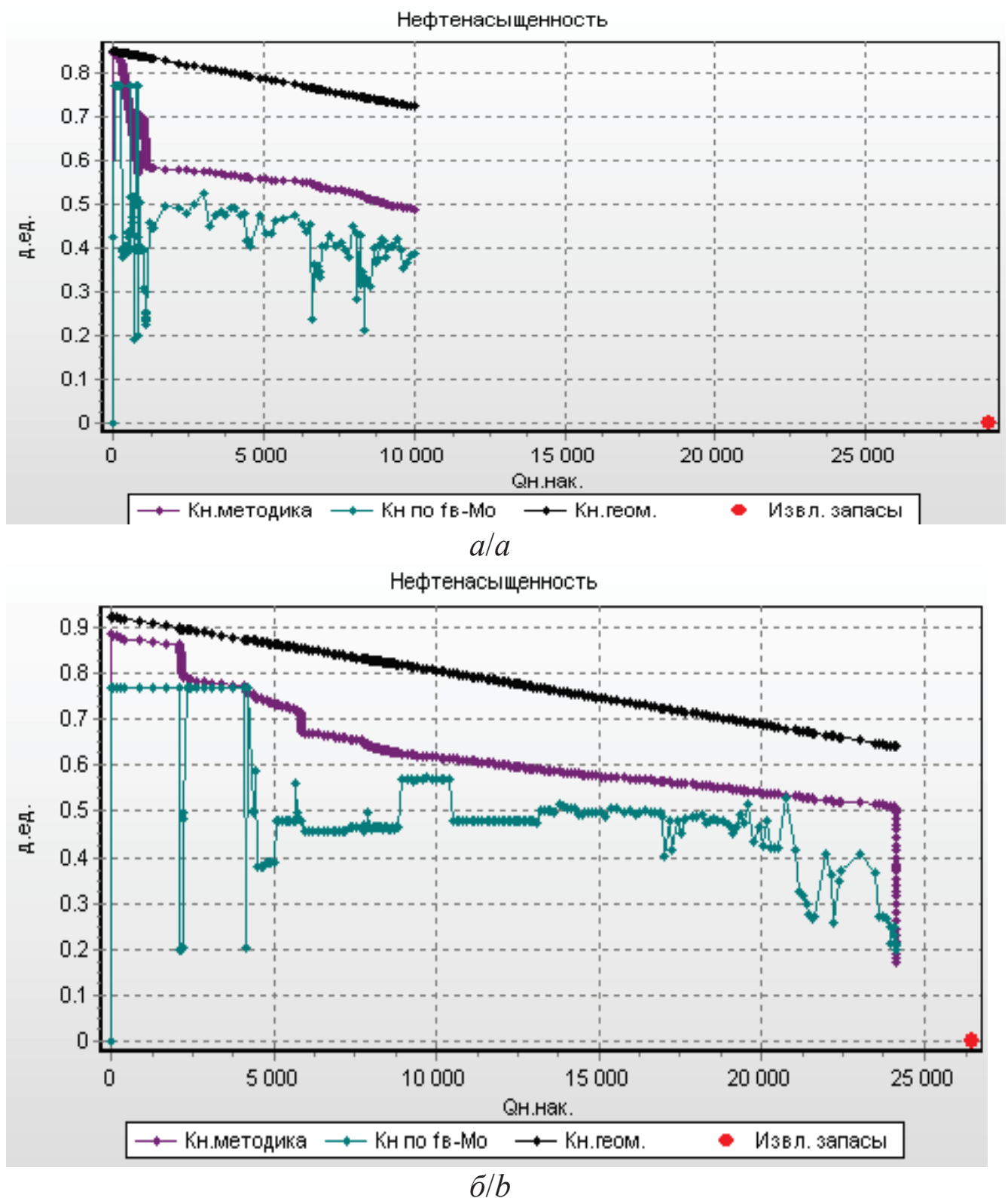

Рис. 7. Динамика оценок текущей нефтенасыщенности для зон скважин-доноров по двум исследуемым группам скважин: а) по первой группе скважин; б) по второй группе скважин

Fig. 7. Dynamics of estimates of current oil saturation for well-acceptance zones for two groups of wells under study: (a) the first ; $b)$ the second

Предлагается следующий способ оценки величины выходящих из дренирования запасов. По кривым оценок текущей насыщенности строятся аппроксимирующие кривые (рис. 8): 1 - оценка текущей нефтенасыщенности по доле воды и 2 оценка текущей нефтенасыщенности по методике.

По кривым рассчитывается разность $d K_{\mathrm{H}}$ на текущий момент безразмерного времени $\left(\Sigma Q_{\mathrm{H}}\right)$ - накопленной добычи нефти. По данным подсчетных параметров вскрывающих пласт добывающих скважин определяем величину выходящих из дренирования запасов, по формуле (7)

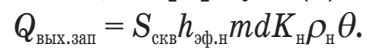

Для нагнетательных скважин данная величина определяется как сумма взвешенных долей потерь дренируемых запасов для всех направлений прорыва от нагнетательной скважины (результаты трассерных исследований). При этом предварительно для добывающих скважин по каждому из работающих направлений влияния закачки (прорыва) определяется доля потерь дренируемых запасов от каждой нагнетательной скважины. Алгоритмы определения выходящих из дренирования запасов для нагнетательных скважин представлены в табл. 1. 


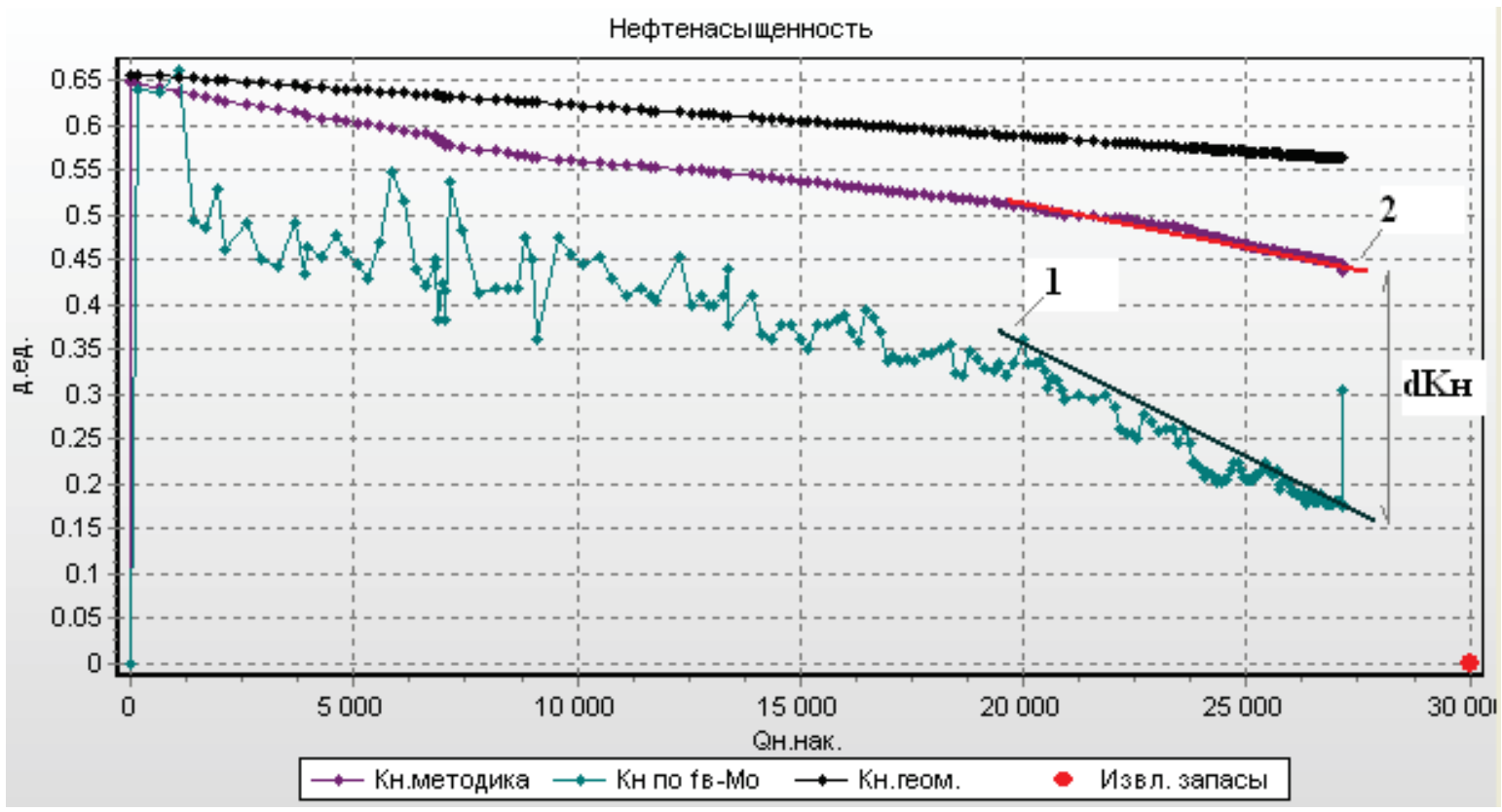

Pис.8. Соотнесение оценок нефтенасыщенности с динамикой технологических показателей

Fig. 8. Correlation between estimates of oil saturation and the dynamics of technological indicators

Определение величины незадействованных запасов нефти (не участвующих в дренировании) $Q_{\text {не.дрен.зап }}$ производится аналогично по формуле (8), но с некоторыми особенностями. Поскольку оценка текущей нефтенасыщенности, определяемой по доле воды, выше оценки по методике, предполагается, что фактическая область дренирования, обеспечивающая приток нефти с несоизмеримо низкой обводненностью, больше области скважины $\left(S_{\text {скв}}\right)$, учитываемой в расчетах остаточных запасов по методике. Другими словами, у скважины есть потенциал, но он не проявляется по балансу отборов и остаточных запасов, т. е. скважина не добирает то, что возможно.

При этом величина $-d K_{\text {н }}$ (определяемая аналогично предыдущему методу) будет показывать долю запасов, не вовлекаемых в дренирование.

$$
Q_{\text {не.дрен.зап }}=S_{\text {скв }} h_{\text {эф.н }} m\left(-d K_{\text {н }}\right) \rho_{\text {н }} \theta \text {. }
$$

Наиболее часто данная особенность проявляется по скважинам, аккумулирующим подток нефти, но обладающим пониженной проницаемостью (менее 20-30 м Дарси). Данные скважины могут представлять интерес при планировании ГРП.

Динамика оценок текущей нефтенасыщенности по скважине-кандидату под ГРП (ГПР проведено фактически) приведена на рис. 9.

По всему фонду скважин основных эксплуатационных объектов Северо-Ореховского месторождения сформированы списки влияющего окружения в радиусе 1500 м. Для каждой добывающей и нагнетательной скважины созданы матрицы входных и выходных параметров по динамике технологических показателей за последние 24 месяца.

Выполнены расчеты параметров математических моделей, рассчитаны векторы подтока от направлений влияния закачки - для добывающих

Таблииа 1. Алгоритм расчетов величин выходящих из дренирования запасов нефти для нагнетательных скважин

Table 1. Algorithm for calculating the values of oil reserves emerging from the drainage for injection wells

\begin{tabular}{|c|c|c|c|c|c|c|}
\hline \multicolumn{6}{|c|}{$\begin{array}{l}\text { Добывающие скважины } \\
\text { Production wells }\end{array}$} & $\begin{array}{c}\text { Нагнетательные скважины } \\
\text { Injection wells }\end{array}$ \\
\hline \multirow[t]{2}{*}{$\begin{array}{c}\text { Направление влияющих } \\
\text { скважин } \\
\text { Direction of impact wells }\end{array}$} & \multicolumn{2}{|c|}{$\begin{array}{l}\text { Приходящий } \\
\text { вектор } \\
\text { Incoming } \\
\text { vector }\end{array}$} & \multirow[t]{2}{*}{$d Q_{\left(\mathbb{W}-\mathrm{H}_{i}\right.}$} & \multirow[t]{2}{*}{$K_{j}=d Q_{i} / \Sigma d Q_{i}$} & $\begin{array}{c}\text { Находим долю выходящих из дренирования } \\
\text { запасов от направления нагнетательной } \\
\text { скважины } \\
\text { Let's find the share of oil reserves emerging } \\
\text { from drain from the injection well direction }\end{array}$ & \begin{tabular}{|c|} 
Суммируем доли по всем \\
направлениям для данной \\
нагнетательной скважины \\
Let's sum the shares on all \\
fronts for the injection well
\end{tabular} \\
\hline & $Q_{\mathrm{H}_{\mathrm{i}}}$ & $Q_{\Psi_{i}}$ & & & $Q_{\text {вых.зап }} \cdot K_{j}$ & $\Sigma Q_{\text {вых.зап }} \cdot K_{i j}$ \\
\hline $\begin{array}{c}\text { Нагнетательная скважина } 1 \\
\text { Injection well } 1\end{array}$ & $Q_{\mathrm{H}_{1}}$ & $Q_{\nVdash_{1}}$ & $d Q_{\left(Ж-\mathrm{H}_{1}\right.}$ & $K_{1}$ & $Q_{\text {выx.sап̆ }}$ & $\Sigma Q_{\text {вых.зап }} K_{1 m}$ \\
\hline $\begin{array}{c}\text { Нагнетательная скважина } 2 \\
\text { Injection well } 2\end{array}$ & $Q_{\mathrm{H}_{2}}$ & $Q_{W_{2}}$ & $d Q_{(Ж-\mathrm{H})_{2}}$ & $K_{2}$ & $Q_{\text {выx.зап, }}$ & $\Sigma Q_{\text {вых.зап }} K_{2 m}$ \\
\hline$\ldots$ & $\ldots$ & $\ldots$ & $\ldots$ & $\ldots$ & $\ldots$ & $\ldots$ \\
\hline $\begin{array}{c}\text { Нагнетательная скважина } n \\
\text { Injection well } n\end{array}$ & $Q_{\mathrm{H}_{i}}$ & $Q_{*_{i}}$ & $d Q_{(\nVdash-\mathrm{H})_{i}}$ & $K_{i}$ & $Q_{\text {Bux.sam }_{j}}$ & $\Sigma Q_{\text {вых.зап }} K_{i j}$ \\
\hline
\end{tabular}




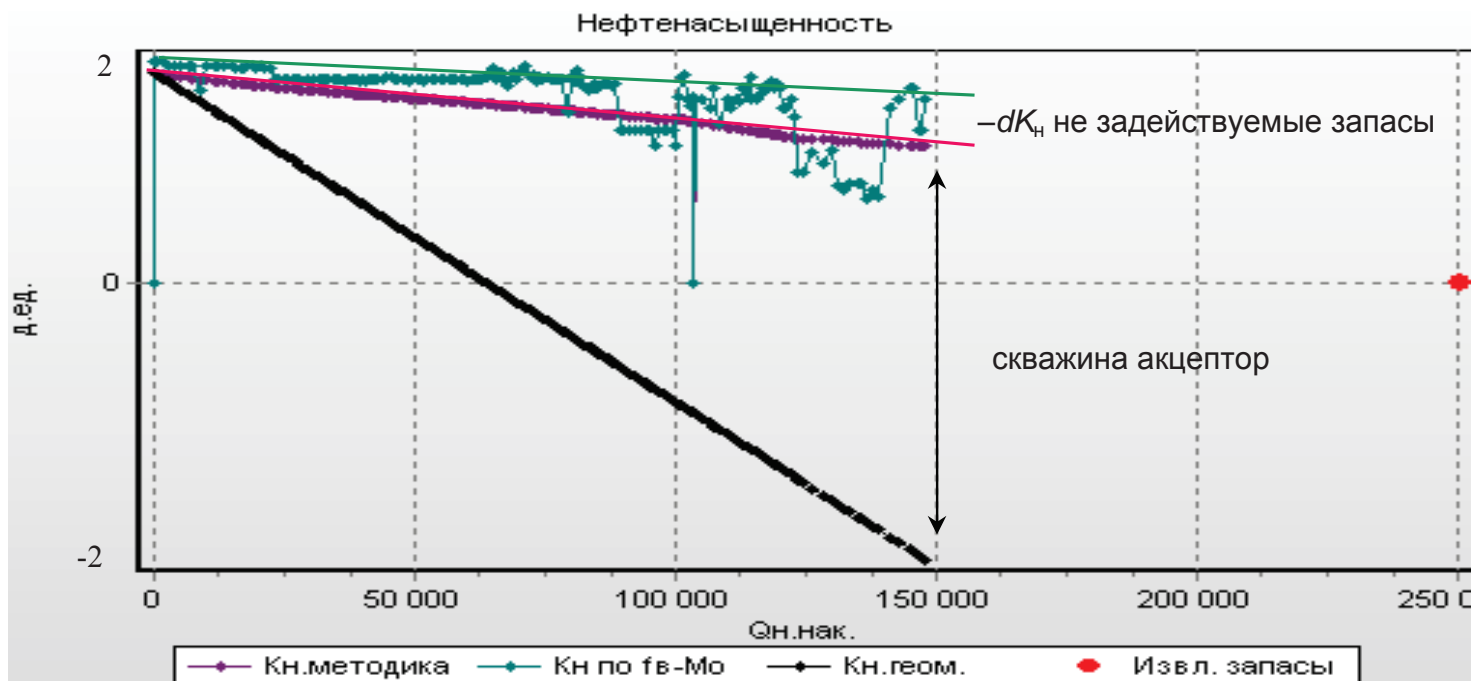

Pис. 9. Динамика оценок текущей нефтенасыщенности по скважине-кандидату под гидравлический разрыв пласта (әидравлический разрыв пласта проведен фактически)

Fig. 9. Dynamics of current oil saturation estimates along a borehole-candidate under hydraulic fracturing (hydraulic fracturing carried out actually)

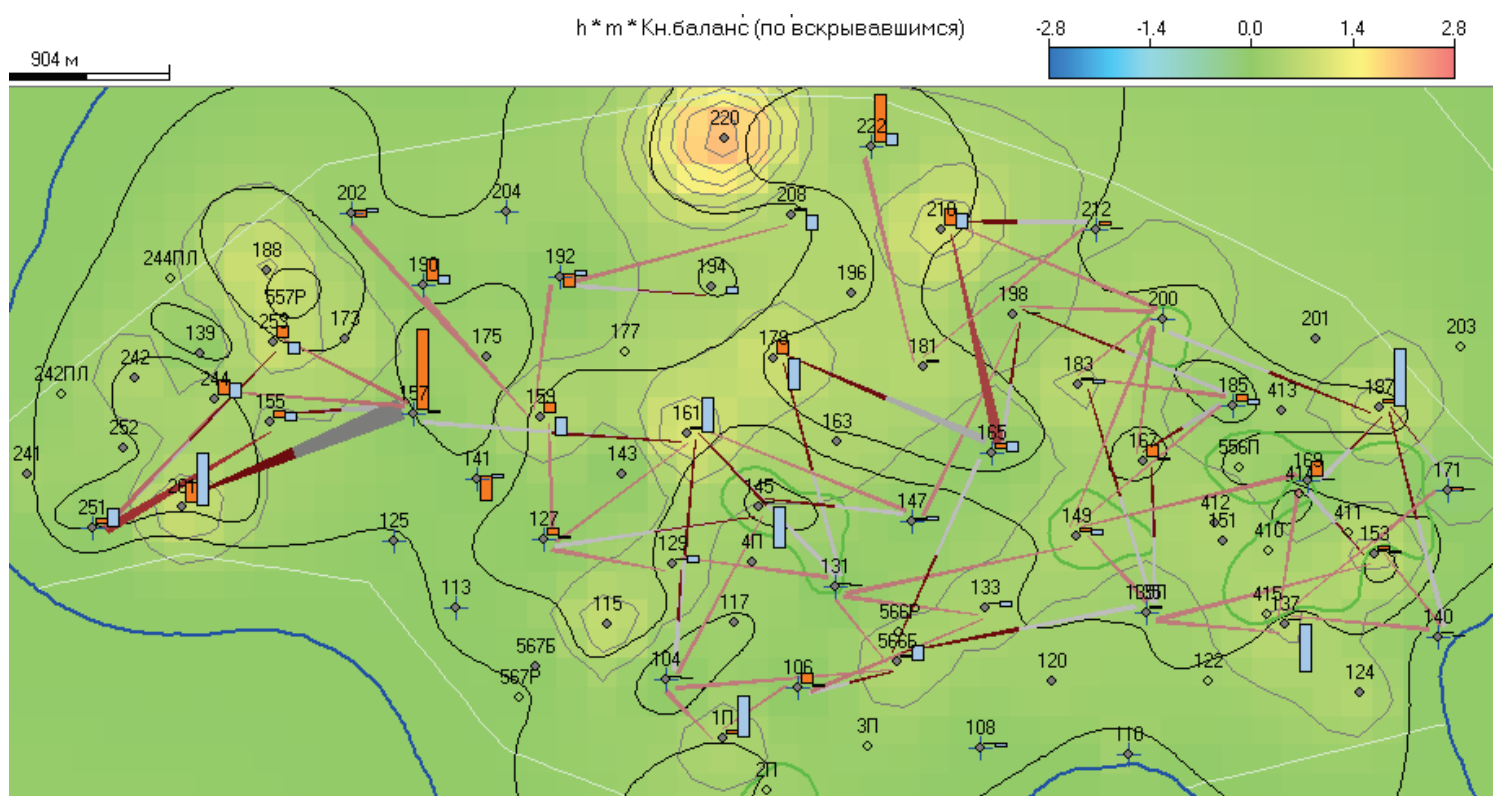

Рис. 10. Соотнесение характера и степени влияния закачки на отборы по нефти, компенсащии отборов закачкой с картой плотности текущих запасов нефти пласта $A B_{2-1}$ (на 01.01.2014 г.)

Fig. 10. Correlation of the nature and extent of injection impact on oil selection, compensation of injection selections with the map current oil reserves density on the reservoir $A V_{2-1}(01.01 .2014)$

скважин, и векторы оттока к отбирающим скважинам - для нагнетательных скважин. Кроме того, выполнены оценки компенсации отборов закачкой для очагов влияния нагнетательных скважин и зон добывающих скважин. Для примера по пласту $\mathrm{AB}_{2-1}$ данные результатов представлены на рис. 10 и в табл. 2,3 .

\section{Подбор кандидатов под ОПЗ}

Первый подход в подборе скважин-кандидатов на проведение работ интенсификации добычи неф- ти базируется на результатах ранее представленного метода. Метод определения величин удельных остаточных балансовых запасов предполагает выявление скважин доноров и акцепторов, данная особенность фиксируется по наличию величины $d Q_{\text {н }}$, которая имеет положительные и отрицательные значения. У скважин доноров, которые теряют свои запасы, отбор нефти меньше.

В зонах дренирования, отдающих свои запасы, мы сталкиваемся с вытеснением нефти водой, допуская, что случается равномерное вытеснение нефти 
Таблица 2. Геолого-технологические показатели и данные характера влияния закачки по фонду добывающих скважин пласта АV $2-1$

Table 2. Geological and technological indicators and the data on the nature of impact of injection in fund of production wells on the reservoir $A V_{2-1}$

\begin{tabular}{|c|c|c|c|c|c|c|c|}
\hline \multirow[b]{2}{*}{$\begin{array}{c}\text { Скважина } \\
\text { Well }\end{array}$} & \multicolumn{4}{|c|}{ Запасы/Reserves (т/t) } & \multirow[b]{2}{*}{ 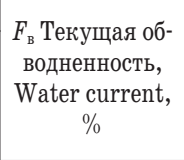 } & \multirow[b]{2}{*}{$\begin{array}{l}\text { Характер потока } \\
\text { Nature of the flow }\end{array}$} & \multirow{2}{*}{$\begin{array}{c}\mathrm{F}_{\text {в}} \text {-КИиЗ, Коэффициент } \\
\text { использования извлекае- } \\
\text { мых запасов } \\
\text { Utilization of recoverable } \\
\text { reserves coefficient, \% }\end{array}$} \\
\hline & \begin{tabular}{|c|} 
Балансовые \\
запасы \\
Balance \\
stocks
\end{tabular} & $\begin{array}{c}\text { Извлекае- } \\
\text { мые запасы } \\
\text { Recoverable } \\
\text { stocks }\end{array}$ & $\begin{array}{c}\text { Остаточные извле- } \\
\text { каемые запасы } \\
\text { Residual recove- } \\
\text { rable tocks }\end{array}$ & $\begin{array}{c}\text { Остаточные балан- } \\
\text { совые запасы } \\
\text { Residual balance } \\
\text { stocks }\end{array}$ & & & \\
\hline 115 & 190781 & 30020 & 2871 & 143341 & 98,7 & - & 8,26 \\
\hline 120 & 75294 & 18 & 6 & 56571 & 80 & - & 14,27 \\
\hline 124 & 321620 & 6562 & 1975 & 248241 & 84,62 & донор/donor & 14,71 \\
\hline 129 & 95241 & 43113 & 5201 & 71936 & 97,31 & \multirow{4}{*}{ акцептор/acceptor } & 9,37 \\
\hline 133 & 129773 & 83389 & 9449 & 97503 & 97,85 & & 9,18 \\
\hline 137 & 116840 & 52692 & 7675 & 91837 & 95,05 & & 9,62 \\
\hline 139 & 11376 & 61253 & 1815 & - & 97,78 & & 0,74 \\
\hline 143 & 176623 & 18962 & 1027 & - & 66,67 & - & $-27,92$ \\
\hline 145 & 79474 & 68900 & 6585 & 60131 & 97,03 & \multirow{2}{*}{ акцептор/acceptor } & 6,58 \\
\hline 149 & 183051 & 88055 & 7761 & 139032 & 98,15 & & 6,96 \\
\hline 151 & 46952 & 210 & 42 & 35277 & 96,15 & - & 16,18 \\
\hline 153 & 165042 & 132150 & 11036 & 114018 & 97,98 & \multirow{4}{*}{ акцептор/acceptor } & 6,33 \\
\hline 155 & 99917 & 149553 & 18686 & 75296 & 97,86 & & 10,36 \\
\hline 159 & 175699 & 136671 & 23127 & 109857 & 96,35 & & 13,28 \\
\hline 161 & 472364 & 130206 & 20045 & 251932 & 96,76 & & 12,15 \\
\hline 163 & 206813 & 12949 & 1451 & 127536 & 97,74 & донор/donor & 8,95 \\
\hline 167 & 98403 & 198936 & 23175 & 75194 & 98,94 & \multirow{4}{*}{ акцептор/acceptor } & 10,59 \\
\hline 173 & 141375 & 140819 & 19489 & 106221 & 99,93 & & 13,77 \\
\hline 175 & 55290 & 57699 & 5735 & 41541 & 99,08 & & 9,02 \\
\hline 179 & 307456 & 198663 & 57476 & 231003 & 96,77 & & 25,7 \\
\hline 181 & 310717 & 4927 & 1895 & 151131 & 98,27 & донор/donor & 36,73 \\
\hline 183 & 204157 & 89440 & 8558 & 158770 & 98,36 & \multirow{2}{*}{ акцептор/acceptor } & 7,93 \\
\hline 187 & 200229 & 118880 & 15453 & 153002 & 97,32 & & 10,32 \\
\hline 188 & 317884 & 56159 & 5402 & 238839 & 99,38 & донор/donor & 9 \\
\hline 194 & 131261 & 17771 & 3246 & 115827 & 93,44 & - & 11,7 \\
\hline 196 & 216764 & 50034 & 4620 & 112692 & 93,33 & \multirow{2}{*}{ акцептор/acceptor } & 2,57 \\
\hline 198 & 181528 & 74711 & 3154 & 30104 & 66,67 & & $-29,11$ \\
\hline 201 & 146525 & 395 & 210 & 110090 & 66,67 & донор/donor & 19,81 \\
\hline 208 & 179706 & 40776 & 12445 & 135020 & 97,86 & - & 28,38 \\
\hline 210 & 540678 & 262752 & 49785 & 406232 & 97,87 & акцептор/acceptor & 16,81 \\
\hline 220 & 2034980 & 8660 & 822 & 1573814 & 99,43 & донор/donor & 8,91 \\
\hline 241 & 56343 & 2493 & 89 & 50085 & 83,33 & - & $-13,11$ \\
\hline
\end{tabular}

с адекватным замещением выработанной части заводненной зоной. При этом выработка извлекаемых запасов (КИиЗ - коэффициент использования извлекаемых запасов) достигает $100 \%$, при $100 \%$ обводнении, а разница долей $F_{\text {в }}$ КИиЗ $=0$. Но чаще в «транзитных» зонах-донорах обводненность опережает выработку запасов с разницей долей $F_{\text {в }}$ КИиЗ $>0$ на 10-20 \% обводненности. Скважины-доноры, поскольку теряют свои запасы из-за смещения, отбирают меньше нефти (относительно своих мощностей), чем ближайшие акцепторы [10, 11 и др.].

Случаи, когда для доноров утечка запасов является ложной, т. е. скважины отбирают меньше своих потенциалов, но смещение их запасов не происходит или происходит, но не в соизмеримо меньшей со снижением отборов нефти степени, мы сталкиваемся с неявным донором. Зона дренирования и не отдает запасы, и не добирает. Для неявных доноров характерно снижение или отсутствие нормального замещения нефти водой и действует условие $F_{\text {в}}$ КИи $3<0$. Подобные недостаточные отборы нефти скважин (или их снижение) с замедлением темпов обводнения могут быть обусловлены снижением проводимости в околоскважинной зоне и увеличением скин-фактора на фоне слабого влияния закачки или законтурной области

Данные скважины могут быть кандидатами на внедрение методов интенсификации добычи нефти, воздействующих на околоскважинную зону, вибро-акустика, гидро-импульсные технологии и т. д. [12, 13 и др.].

Второй подход в подборе скважин-кандидатов под ОПЗ более универсален, поскольку позволяет выявлять скважины с недостаточной выработкой при существующем потенциале (водоограничивающие, гидрофобизирующие МУН).

Данный подход предполагает принцип оценки относительной динамики отборов нефти и выявление несоотносимо высоких с остаточным потенциалом темпов падения добычи нефти $[14,15$ и др.]. Для этого по фонду скважин производится оценка начальных извлекаемых запасов, а также темпов падения отборов от текущих (остаточных) извлекаемых запасов (Кгтм) на каждый момент времени работы скважины. Динамика темпов падения отборов нефти от остаточных запасов по пласту $\mathrm{A}_{2-1}$ Северо-Ореховского месторождения [16] представлена на рис. 11. 
Таблица 3. Геолого-технологические показатели и данные характера влияния закачки по фонду нагнетательных скважин пласта $A B_{2-1}$

Table 3. Geological and technological indicators and the data on the nature of impact of injection in fund of injection wells on the reservoir $A V_{2-1}$

\begin{tabular}{|c|c|c|c|c|c|c|}
\hline $\begin{array}{c}\text { Скважина } \\
\text { Well }\end{array}$ & $\begin{array}{c}F_{\text {в }} \\
\text { Обводненность продукции } \\
\text { скважин окружения } \\
\text { Flooding of the products of } \\
\text { the environment wells, \% }\end{array}$ & $\begin{array}{c}h \text { недр, м } \\
\text { Bowels l, m }\end{array}$ & $\begin{array}{c}Q_{\text {бал.ост.окр }}, \\
\text { Кол-во балансовых ос- } \\
\text { таточных запасов сква- } \\
\text { жин окружения, т } \\
\text { Balance residual envi- } \\
\text { ronment, t }\end{array}$ & $\begin{array}{c}Q_{\text {н.бал.ост }} \\
\text { Кол-во балансовых ос- } \\
\text { таточных запасов, т } \\
\text { Balance residual, t }\end{array}$ & $\begin{array}{c}F_{\text {в }} \text { КИиЗ, } \\
\text { Коэффициент ис- } \\
\text { пользования извле- } \\
\text { каемых запасов } \\
\text { Utilization of recove- } \\
\text { rable reserves, \% }\end{array}$ & $\begin{array}{c}\text { Потери дренируе- } \\
\text { мых запасов за счет } \\
\text { обводнения, т } \\
\text { Loss of drained } \\
\text { stocks due to floo- } \\
\text { ding, t }\end{array}$ \\
\hline 104 & 94,11 & 0 & 49163,75 & - & & 0 \\
\hline 106 & 93,54 & 0 & 94621,35 & - & 43,49 & 112915,7 \\
\hline 108 & 94,02 & 0 & 96831,67 & 7285,15 & - & 31730 \\
\hline 110 & 87,88 & 0,8 & 356454,2 & 84330,33 & 56,41 & 0 \\
\hline 113 & 93,47 & 0,8 & 48668,34 & 1296,65 & 59,03 & 0 \\
\hline 125 & 95,75 & 0 & 129431,4 & 15549,7 & - & 0 \\
\hline 127 & 94,45 & 0,8 & 33856,87 & 43,57 & 21,83 & 98625,75 \\
\hline 131 & 94,1 & 0 & 211126,5 & 21,59 & 4,57 & 22316,17 \\
\hline 135 & 90,34 & 0 & 402283,8 & 49626,66 & 19,41 & 38187,25 \\
\hline 140 & 87,18 & 0 & 349467,3 & 6550,74 & - & 20004,72 \\
\hline 141 & 95,2 & 1,2 & 49305,13 & 2523,98 & 42,18 & 55536,13 \\
\hline 147 & 94,21 & 0,8 & 229111,1 & $-58723,94$ & 4,44 & 35349,43 \\
\hline 157 & 95,45 & 0 & 100174,6 & 1081,64 & $-9,32$ & 320387 \\
\hline 165 & 91,65 & 3,2 & 294952,1 & 379,64 & 42,62 & 216736 \\
\hline 169 & 88,4 & 0 & 410502,5 & - & - & 98770,49 \\
\hline 171 & 84,62 & 3 & 349467,3 & 30675,53 & 3,47 & 0 \\
\hline 185 & 86,77 & 3,4 & 142497,7 & 8875,46 & 10,24 & 177821,3 \\
\hline 190 & 94,6 & 2 & 45390,37 & 15464,42 & 24,48 & 56705,52 \\
\hline 192 & 94,03 & 0 & 32238,7 & - & 60,32 & 0 \\
\hline 200 & 87,05 & 4,8 & 228308,5 & 195361,72 & 68,05 & 26263,45 \\
\hline 202 & 98,18 & 1,8 & 43509,26 & 55412,55 & 37,19 & 2949,3 \\
\hline 204 & 97,95 & 1 & $-9594,63$ & 107610,8 & 21,25 & 0 \\
\hline 212 & 88,24 & 0 & 139444,2 & 179503,99 & - & 18537,13 \\
\hline 222 & 92,95 & 2,8 & 146505,1 & 147708,63 & 11,08 & 513858,3 \\
\hline 251 & 96,32 & 1 & 125252,5 & 4474,74 & 8,74 & 52264,79 \\
\hline
\end{tabular}

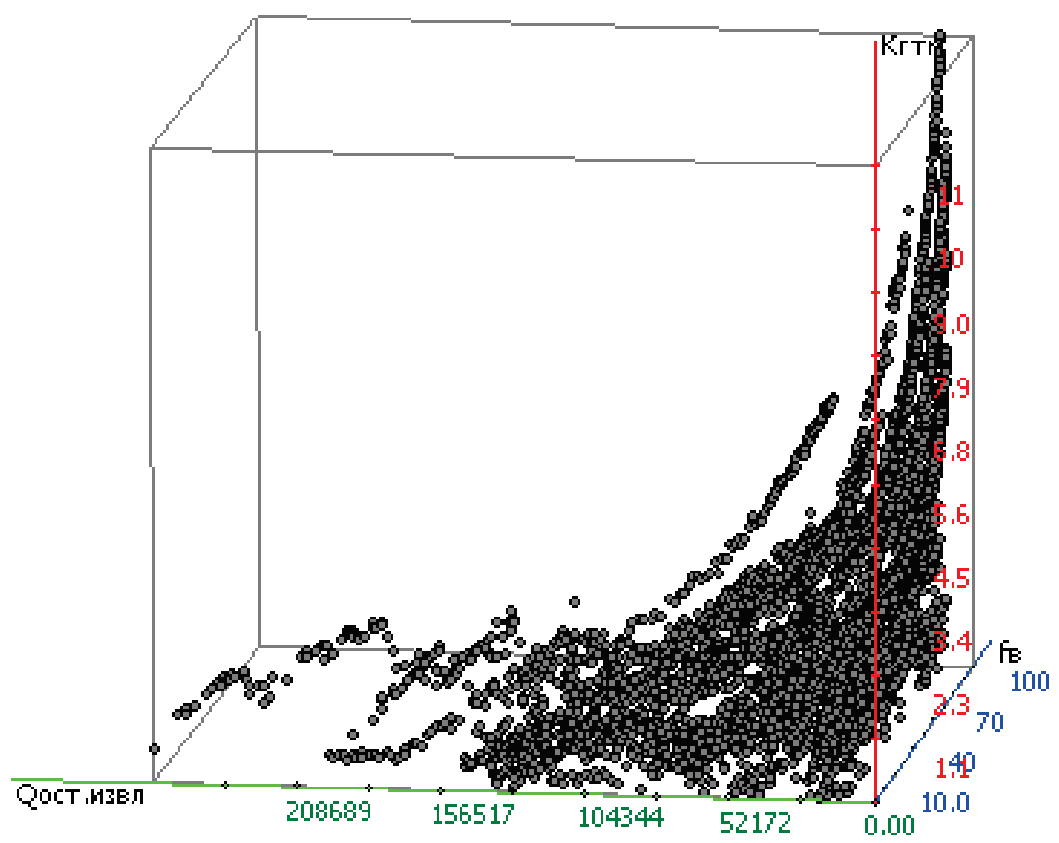

Рис. 11. Функиия относительного падения отборов нефти в координатах остаточных извлекаемых запасов и текущей обводненности за все время эксплуатаиии скважин

Fig. 11. Function of oil production relative decline in the coordinates of the residual recoverable reserves and the current watering during all well operations 


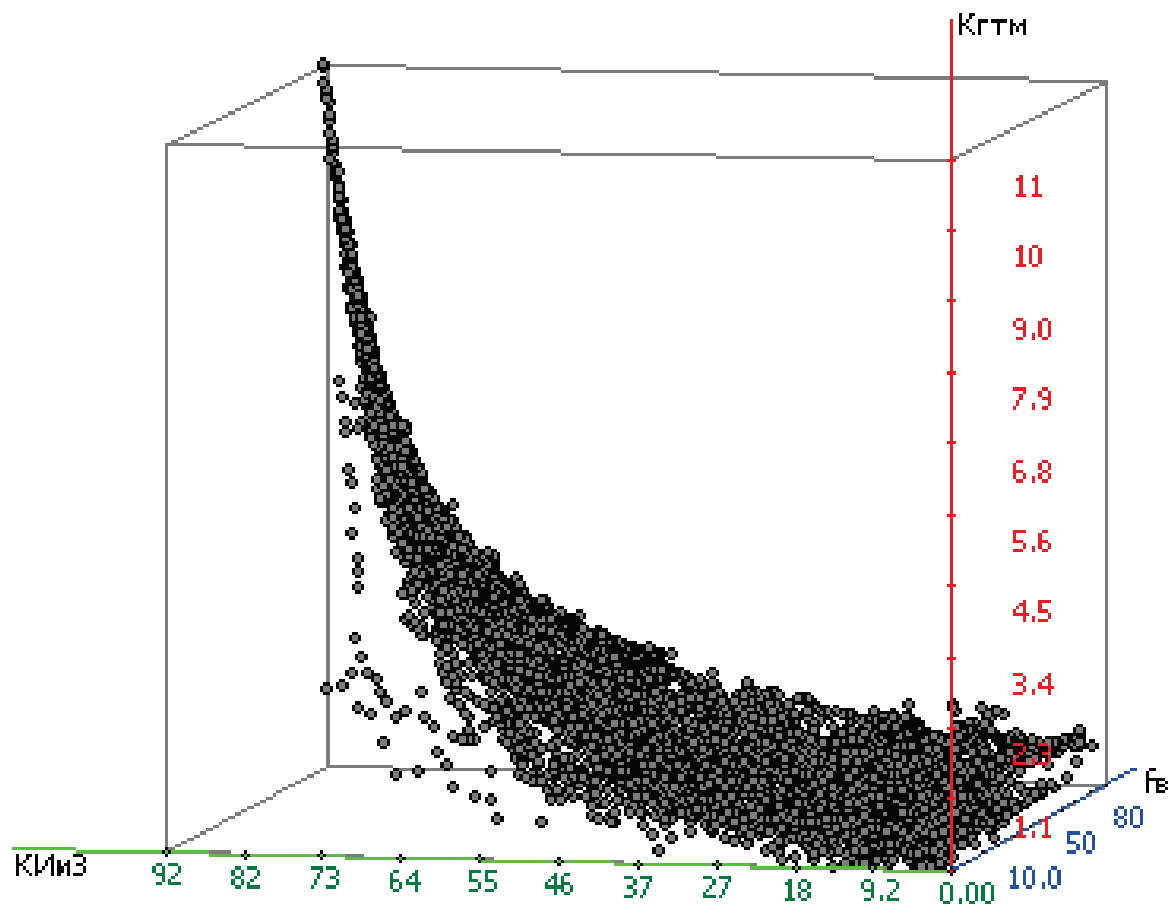

Рис. 12. Функиия относительного падения отборов нефти в координатах относительных остаточных извлекаелых запасов нефти и текущей обводненности за все время эксплуатации скважин

Fig. 12. Function of oil production relative decline in coordinates of relative residual of recoverable oil reserves and the current watering during all well operations

Для того, чтобы нивелировать относительность уровней падения добычи нефти фонда скважин и их остаточных запасов, производится нормирование величин падения отборов нефти по относительным остаточным извлекаемым запасам (текущим извлекаемым запасам ТИЗ=1-КИиЗ).

Представление темпов падения отборов нефти по фонду скважин в координатах текущие извлекаемые запасы (ТИЗ) - текущая обводненность позволяет получить четкую степенную зависимость следующего вида (рис. 7).

По представленной зависимости видно, что на фоне общей поверхности выделяются скважины, отстоящие (с $K_{\text {гтм }}$ выше) от общей поверхности точек.

Далее создается аппроксимирующая поверхность математическая модель вида:

$$
K_{\text {гтм }}=f\left(n \mathrm{TИ}^{n}, f_{\mathrm{B}}\right) .
$$

К ОПЗ рекомендуются скважины, по которым в течение последних нескольких месяцев данные фактических темпов падения выше аппроксимирующих значений по модели при уже существующих относительных текущих извлекаемых запасах и обводненности [17-20]. Ниже представлен пример соотношения фактических уровней падения добычи нефти (красный маркер) и оптимальных значений (фиолетовый маркер) при заданной выработке и обводненности по добывающей скважине 347 пласта $\mathrm{A}_{2-1}$ (рис. 12).

Предложенный метод может быть дополнен анализом динамик темпов отборов нефти от остаточных извлекаемых запасов в безразмерном вре- мени остаточных извлекаемых запасов (рис. 13).

Пользуясь данной методикой, можно не только подобрать скважину под мероприятие, но и определить, когда, например, проводилось ГТМ, и какая была его результативность. Ниже представлена динамика предлагаемых параметров по скважине 601 пласта $\mathrm{A}_{1-3}$.

Представленные характеристики подтверждают: во-первых, целесообразность проводимых мероприятий, во-вторых, наличие эффекта от мероприятия. Темпы добычи нефти после ГТМ замедляются, темпы отбора жидкости увеличиваются. Фактический отбор до мероприятия ниже критических значений по двум из трех потенциальных характеристик (рис. 14).

Третий методический подход часто используется в нефтепромысловой практике подбора мероприятий. В его основе лежит предположение, что технологическая эффективность мероприятий (исключая успешность, случайный фактор) тесно связана с геолого-технологическими параметрами, характеризующими потенциал скважин, - остаточные извлекаемые запасы, эффективная нефтенасыщенная мощность, площадь зоны дренирования, проницаемость и т. д. [21]. Достоинством данного подхода является то, что он совмещает в себе свойства прогноза технологической эффективности и критериального обоснования. Метод подходит не только для подбора ОПЗ, но и для групп технологий увеличения нефтеотдачи различной специфики (по механизму вовлечения незадействованных запасов нефти). Метод основывается на 


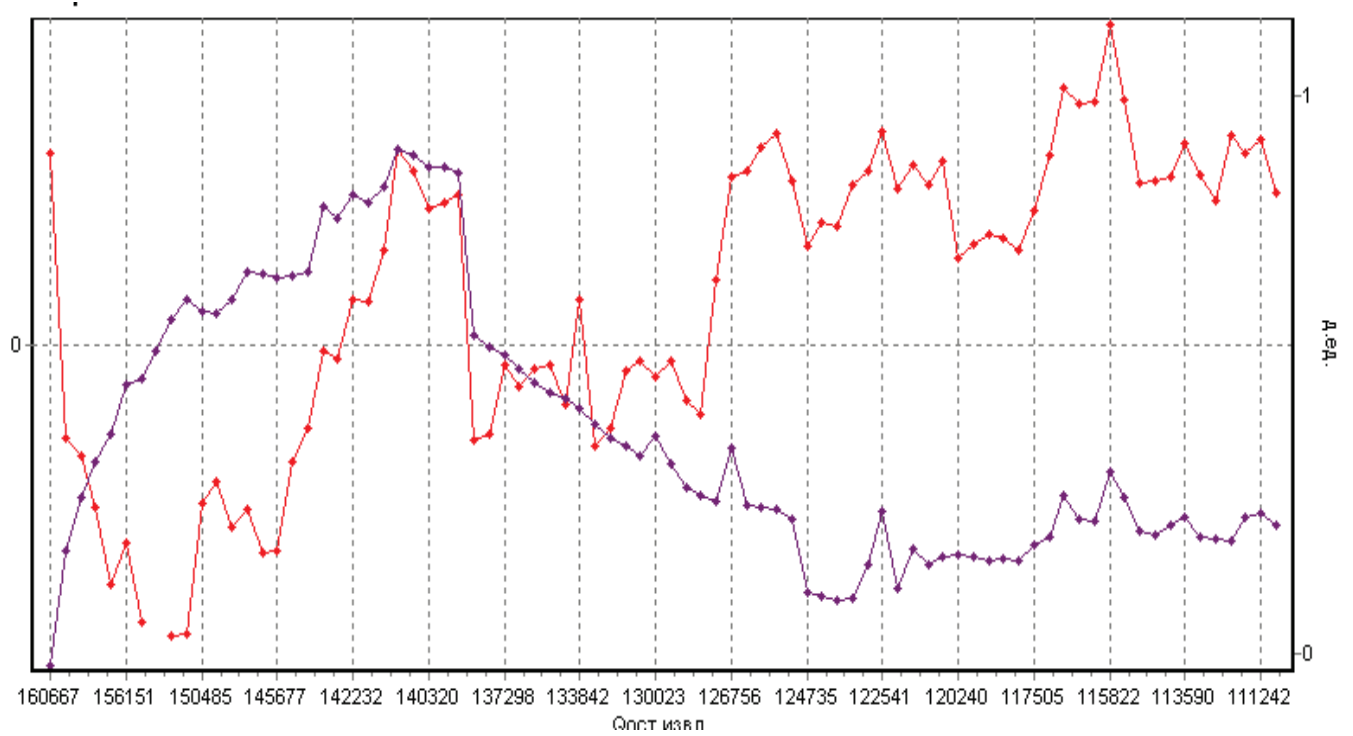

Рис. 13. Скважина 347, пласт $A_{2-1}$. Превышение оптимальных уровней падения отборов нефти при заданной выработке и обводненности

Fig. 13. Borehole 347, reservoir $A_{2-1}$. Exceeding optimum levels of falling oil production for given development and watering

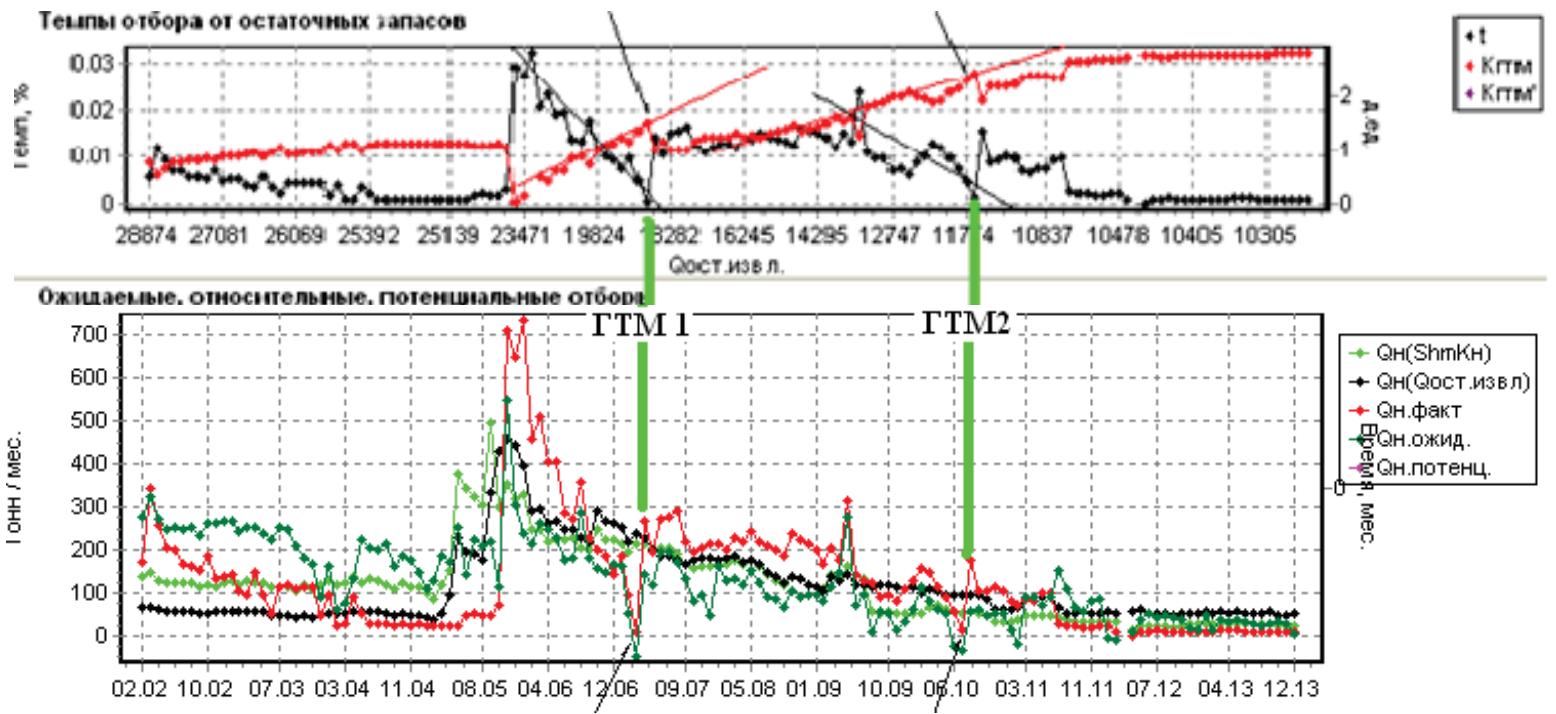

Pис. 14. Подтверждение методических подходов в обосновании обработки призабойной зоны по скважине 601 пласта $A_{1-3}$ Cеверо-Ореховского месторождения

Fig. 14. Confirmation of methodical approaches to justify the processing of bottomhole formation zone along a borehole reservoir, 601 , layer $A_{1-3}$, Severo-Orekhouskoe deposit

применении процедуры расчетов параметров множественного регрессионного анализа. Искомой функцией является технологическая эффективность от мероприятий (за год или за месяц), а аргументами - набор геолого-технологических показателей фонда скважин на дату проведения мероприятия. По данным имеющихся наблюдений по эффектам, времени, видам мероприятий и геологотехнологическими признаками скважин создаются матрицы параметров $X$ и $Y$. Применение к матрицам параметров алгоритмов расчетов позволяют получить прогнозную модель вида

$$
Y=a+b_{1} x_{1}+b_{2} x_{2}+b_{3} x_{3}+\ldots+b_{n} x_{n} .
$$

Поскольку прогнозная модель отражает в себе вес влияния каждого из учтенных факторов на технологическую эффективность, она же является и математической функцией, которая максимизирует ожидаемый эффект по набору геолого-технологических показателей скважин и реализует в себе свойства критериального подбора.

Актуальным является расчет параметров значимости модели $R^{2}$ и $F$-значения, $S$-прогноза. В качестве прогнозных рекомендуется пользоваться моделями со значениями $R^{2}$ более 0,8 д.ед. и ошиб- 
кой прогноза $S$ менее $15 \%$. Модели с $R^{2}$ от 0,5 до 0,7 с увеличением значений $S$ приобретают свойства оценочных и больше подходят для критериального анализа и подбора.

\section{Заключение}

Проведенный анализ существующих методических подходов подбора скважин-кандидатов на проведение мероприятий по обработке призабойной зоны скважин Северо-Ореховского месторождения показал, что применение данных методических подходов позволяет решить ряд нефтепромысловых задач:

\section{СПИСОК ЛИТЕРАТУРЫ}

1. Максимов М.И. Геологические основы разработки нефтяных месторождений. - М.: Недра, 1975. - 534 с.

2. Токарев М.А. Комплексный геолого-промысловый контроль за текущей нефтеотдачей при вытеснении нефти водой. - М.: Недра, 1990. - 267 с.

3. Ефимов Н.К. Технологии ОВП в нефтяных скважинах и пути повышения эффективности РИР // Инженерная практика. 2011. - № 7. - C. $2-17$.

4. Хавкин А.Я. Физико-химические технологии повышения нефтеотдачи низкопроницаемых пластов // Нефтяное хозяйство. - 1994. - № 8. - С. 31-34.

5. Вайншток С.М., Хайрединов Н.Ш., Андреев В.Е. Геолого-технологические особенности разработки месторождений Когалымского региона с применением методов увеличения нефтеотдачи. - Уфа: Изд-во, Изд-во УГНТУ, 1999. - 156 с.

6. Габсия Б.К., Никитина И.Н. Особенности моделирования углеводородной фазы в фильтрационных экспериментах // Нефтяное хозяйство. - 2016. - Ч. 2. - С. 44-46.

7. Гидродинамические методы регулирования разработки нефтяных месторождений / Ю.В. Зейгман, 0.А. Гумеров, Р.М. Каримов, Г.А. Шамаев // Актуальные вопросы разработки нефтегазовых месторождений на поздних стадиях. Технологии. Оборудование. Безопасность. Экология: Материалы научно-практической конференции. - Уфа: Изд-во УГНТУ, 2010. C. $167-172$.

8. Зайцев М.В., Михайлов Н.Н., Сарбаев К.А. Влияние изменений остаточной водонасыщенности в околоскважинной зоне пласта на дебит добывающих скважин // Нефтяное хозяйство. - 2017. - № 9. - С. 90-95.

9. Мухаметшин В.В. 0 необходимости и создании единого комплексного метода геолого-промыслового анализа и обобщения эффективности воздействия на призабойную зону пласта // Нефтяное хозяйство. - 2017. - № 4. - С. 80-84.

10. Вахрушев В.В., Мельников В.Н., Москвитин С.А. Обобщение опыта разработки объекта ЮВ1 месторождений 000 «Лукойл - Западная Сибирь» для повышения обоснованности прогноза технологических показателей // Нефтяное хозяйство. - 2016. - № 8. - С. 44-47.

11. Моделирование кислотной обработки призабойной зоны скважины с учетом ее ухудшенных фильтрационно-емкостных ха-
- определить объем выходящих из дренирования запасов (подбор водоограничивающих МУН, РИР, коррекция режимов работы скважин, остановки); - определить величину незадействованных запасов нефти, не участвующих в дренировании (ГРП, уплотнение);

- оценить достижимость выработки извлекаемых запасов, оцениваемых по общепринятым характеристикам вытеснения, по добывающим скважинам, т. е. произвести их коррекцию.

Авторы благодарят А.С. Глазырина за внимательную проработку статьи и замечания, способствующие улучшению понилания и аргументации выводов.

рактеристик / К.А. Турегелдиева, У.К. Жапбасбаев, Б.К. Асилбеков, А.Б. Золотухин // Нефтяное хозяйство. 2016. - № 4. - Ч. 2. - C. 108-110.

12. Старковский А.В. Комплексное применение физико-химических технологий воздействия для увеличения нефтеотдачи пластов // Нефтяное хозяйство. - 2011. - № 5. - С. 92-95.

13. Анализ выполнения проектных показателей за 2013 г. и разработка мероприятий по реализации проектных решений на 2014 г. по ОАО «СН-МНГ». Отчет о НИР. - Мегион: Изд-во OAO «CH-MHГ» 2014. - T. 14. - $312 \mathrm{c.}$

14. Comparative Studies on Enhanced Oil Recovery: Thermoviscosifying Polymer Versus Polyacrylamide / Xian'e Li, Zhi Xu, Hongyao Yin, Yujun Feng, Hongping Quan // Energy fuels. - 2017. V. 31. - № 3. - P. 2107-3328,

15. Comparative Studies on Enhanced Oil Recovery: Thermoviscosifying Polymer Versus Polyacrylamide / Xian'e Li, Zhi Xu, Hongyao Yin, Yujun Feng, Hongping Quan // Energy fuels. - 2017. V. 31. - № 3. - P. 2479-2487.

16. Advances in improved/enhanced oil recovery technologies for tight and shale reservoirs / Lei Wang, Ye Tian, Xiangyu Yu, Cong Wang, Bowen Yao, Shihao Wang, Ph.H. Winterfeld, $\mathrm{Xu}$ Wang, Zhenzhou Yang, Yonghong Wang, Jingyuan Cui, YuShu Wu // Fuel. - 2017. - V. 210. - P. 425-445.

17. Xiukun Wang, Sheng J.J. Effect of low-velocity non-Darcy flow on well production performance in shale and tight oil reservoirs // Fuel. - 2017. - V. 190. - P. 41-46.

18. Etminan R., Maini B.B., Chen Zh. Determination of mass transfer parameters in solvent-based oil recovery techniques using a non-equilibrium boundary condition at the interface // Fuel. 2017. - V. 120. - P. 218-232.

19. Xiukun Wang, Sheng J.J. Discussion of liquid threshold pressure gradient // Petroleum. - 2017. - V. 3. - Iss. 2. - P. 232-236.

20. Etminan S.R., Maini B.B., Chen Zh. Modeling the interface resistance in low soluble gaseous solvents-heavy oil systems // Fuel. - 2013. - V. 105. - P. 672-687.

21. Speight J.G. Production of syngas, synfuel, bio-oils, and biogas from coal, biomass, and opportunity fuels // Fuel Flexible Energy Generation. - 2016. - № 5. - P. 145-174.

Поступила 12.11.2018 г.

\section{Информация об авторах}

Дягилев В.Ф., кандидат технических наук, доцент кафедры нефтегазового дела Тюменского индустриального университета. 


\title{
APPROBATION OF METHODS FOR PREDICTING OIL RESERVES PRODUCTION AND ESTIMATE TECHNOLOGICAL EFFICIENCY WHEN SELECTING WELLS-CANDIDATES FOR BOTTOM-HOLE ZONE PROCESSING BY THE EXAMPLE OF THE SEVERO-OREKHOVSKOE FIELD
}

\author{
Valeriy F. Dyagilev', \\ glibazval.dyagilev@yandex.ru \\ 1 Tyumen Industrial University, \\ 38, Volodarsky street, Tyumen, 625000, Russia.
} The relevance of the research is caused by the need to assess the current state of oil reserves quality in bottom-hole zones and to pre-
dict technological efficiency of the existing oil reserves production in selection of wells-candidates for bottom-hole zone processing,
which meets the needs of global practices in finding the most effective methods of oil-gas field development. The majority of oil fields
in West Siberia are at the late stage of development. In this regard, the development of remaining reserves becomes a priority. To make
design decisions for predicted development period the assessment of remaining hydrocarbons in place is required, which determines the timeliness of the study and adaptation of field resources assessment methods.

The aim of the research is to improve the efficiency of field development through the introduction of modern techniques which will effect the possibility of determining the values of changes in oil reserves by the example of the Severo-Orekhovskoe field and analyze the techniques used in the Severo-Orekhovskoe field enabling prediction of the technical efficiency of production and estimation of oil reserves in the selection of wells-candidates for bottom-hole zone processing.

Object of the research is the Severo-Orekhovskoe field as an energy complex, where not only traditional techniques of predicting the technological efficiency of oil reserves production are used, but absolutely new methods of oil reserves assessment in selection of wellscandidates for bottom-hole zone processing are tested.

Methods: prediction making it possible to understand the technological efficiency of production and estimation of oil reserves in selection of wells-candidates for bottom-hole zone processing; method of determining the specific remaining reserves values stipulating the use of comparative analysis of the capacity of wells-donors and wells-acceptors; analysis and assessment of values resulting from the reserves drainage; evaluation of the current oil saturation.

Results. The authors have applied the comparative analysis of existing methods of predicting the technological efficiency of production and estimation of oil reserves used in selection of wells-candidates for bottom-hole zone processing. They proposed the modified method for determining specific remaining reserves, which allows estimating the reserves and production of the entire facility for each producing well, as well as reservoir properties of the entire well stock. It was established that the method of determining specific remaining reserves involves identification of wells-donors and wells-acceptors. It was found out that the approach used in the selection of wells-candidates for bottom-hole zone processing is universal, as it allows identifying wells with insufficient production under the existing capacity. Moreover, this methodological approach involves the assessment of oil production relative dynamics and identification of oil rate drop incomparable with residual potential. It was shown that the methodological approach combining the properties of the expected technological efficiency prediction and the criterion justification is based on calculation of multiple regression analysis parameters. It was established that it is based on the assumption that measure technological efficiency (excluding success, random factor) is closely related to geological and technological parameters that characterize the potential of wells: remaining recoverable reserves, sand count, drainage area, permeability, etc. It was proved that this method does not only meet the selection of bottom-hole zone processing, but the groups of technologies for increasing oil recovery of different specificity (according to a mechanism of involvement of idle oil reserves) as well; the desired function is the technological efficiency of activities (per year or per month), and the arguments are a set of well stock geological-technological parameters on the date of the event. The technique of definition of well stock remaining oil reserves was suggested, which contributes to determining the oil reserves quality for a separate production well and allows estimating the reserves and production of the whole facility, as well as reservoir parameters of the whole well stock.

Conclusions. It was established that the specific features of the existing techniques identified during the analysis allow solving a number of oilfield tasks: to determine the reserves volume coming out of the drainage area (selection of water-restriction methods to increase oil output, cement squeeze, well operation condition correction, well shut-off); to define the extent of idle oil reserves not involved in drainage (hydraulic fracturing, compaction); to analyze the reachability of recoverable reserves production, estimated according to the generally accepted characteristics of displacement in producing wells, that is, to make their correction.

\section{Key words:}

Bottom-hole zones, method of determining the remaining reserves of a well stock, method of predicting the technological efficiency of oil-gas reserves production and evaluation, Severo-Orekhovskoe field.

The author is thankful to A.S. Glazyrin for paper elaboration and comments for improving comprehension and reasoning the conclusions.

\section{REFERENCES}

1. Maksimov M.I. Geologicheskie osnovy razrabotki neftyanykh mestorozhdeniy [Geological bases of development oil fields]. Moscow, Nedra Publ., 1975. $534 \mathrm{p}$.

2. Tokarev M.A. Kompleksny geologo-promyslovy kontrol za tekushchey nefteotdachey pri vytesnenii nefti vodoy [Comprehensi- ve geologic monitoring of current oil recovery when oil is displaced by water]. Moscow, Nedra Publ., 1990. 267 p.

3. Efimov N.K. Tekhnologii OVP v neftyanykh skvazhinakh i puti povysheniya effektivnosti RIR [ORP technologies in oil wells and ways to improve the efficiency of RIR]. Engineering practice, 2011, no. 7, pp. 2-17. 
4. Khavkin A.Ya. Physico-chemical technologies of enhanced oil recovery in low-permeability reservoirs. Oil Industry, 1994, no. 8, pp. 31-34. In Rus.

5. Weinstock S.M., Khayredinov N.Sh., Andreev V.E. Geologotekhnologicheskie osobennosti razrabotki mestorozhdeniy Kogalymskogo regiona s primeneniem metodov uvelicheniya nefteotdachi [Geological and technological features of development of deposits of Kogalym region with application of methods of enhanced oil recovery]. Ufa, UGNTU Publ., 1999. 156 p.

6. Gabcia B.K., Nikitina I.N. The details of modeling hydrocarbon phase in the filtration experiments. Oil Industry, 2016, no. 2, pp. 44-46. In Rus.

7. Seigman Yu.V., Gumerov 0.A., Karimov R.M., Shamaev G.A. Gidrodinamicheskie metody regulirovaniya razrabotki neftyanykh mestorozhdeniy [Hydrodynamic methods of regulating the development of oil fields]. Aktualnye voprosy razrabotki neftegazovykh mestorozhdeniy na pozdnikh stadiyakh. Tekhnologii. Oborudovanie. Bezopasnost. Ekologiya. Materialy nauchno-prakticheskoy konferentsii [Topical issues of oil and gas development in the later stages. Technology. Equipment. Security. Ecology. Materials of scientific-practical conference]. Ufa, UGNTU Publ., 2010. pp. $167-172$.

8. Zaitsev M.V., Mikhailov N.N., Sarbaev K.A. The effects of changes in residual water saturation in the borehole zone of the formation on flow rate of producing wells. Oil Industry, 2017, no. 9, pp. 90-95. In Rus.

9. Mukhametshin V.V. On the need and creation of a single comprehensive method of geological analysis and synthesis of impact on the bottomhole formation zone. Oil Industry, 2017, no. 4, pp. 80-84. In Rus.

10. Vakhrushev V.V., Moskvitin V.N., Melnikov S.A. Synthesis of experience in developing an object YuV1 of fields of LLC Lukoil Western Siberia for increase in validity of the forecast of technological indicators. Oil Industry, 2017, no. 4, pp. 80-84. In Rus.

11. Turegeldieva K.A., Zhapbasbaev U.K., Asilbekov B.K., Zolotukhin A.B. Modeling of acid processing of a bottomhole zone of the well taking into account its worsened filtration and capacitor characteristics. Oil Industry, 2016, vol. 2, no. 4, pp. 108-110. In Rus.
12. Starkovskiy A.V. Integrated application of physico-chemical technologies for increasing reservoir recovery. Oil Industry, 2011, no. 5, pp. 92-95. In Rus.

13. Analiz vypolneniya proektnykh pokazateley za 2013 g. i razrabotka meropriyatiy po realizatsii proektnykh resheniy na 2014 g. po $O A O$ «SN-MNG». Otchet o NIR [Analysis of implementation of the project indicators for 2013 and elaboration of measures for implementation of project decisions on 2014, OJSC «CH-TAE»]. Megion, $O A O$ «SN-MNG», 2014. Vol. 14, 312 p.

14. Xian'e Li, Zhi Xu, Hongyao Yin, Yujun Feng, Hongping Quan. Comparative Studies on Enhanced Oil Recovery: Thermoviscosifying Polymer versus Polyacrylamide. Energy fuels, 2017, vol. 31, no. 3, pp. 2107-3328.

15. Xian'e Li, Zhi Xu, Hongyao Yin, Yujun Feng, Hongping Quan. Comparative Studies on Enhanced Oil Recovery: Thermoviscosifying Polymer versus Polyacrylamide. Energy fuels, 2017, vol. 31, no. 3, pp. 2479-2487.

16. Lei Wang, Ye Tian, Xiangyu Yu, Cong Wang, Bowen Yao, Shihao Wang, Winterfeld Ph.H., Xu Wang, Zhenzhou Yang, Yonghong Wang, Jingyuan Cui, Yu-Shu Wu. Advances in improved/enhanced oil recovery technologies for tight and shale reservoirs. Fuel, 2017, vol. 210, pp. 425-445.

17. Xiukun Wang, Sheng J.J. Effect of low-velocity non-Darcy flow on well production performance in shale and tight oil reservoirs. Fuel, 2017, vol. 190, pp. 41-46.

18. Etminan S.R., Maini B.B., Chen Zh. Determination of mass transfer parameters in solvent-based oil recovery techniques using a non-equilibrium boundary condition at the interface. Fuel, 2017, vol. 120, pp. 218-232.

19. Xiukun Wang, Sheng J.J. Discussion of liquid threshold pressure gradient. Petroleum, 2017, vol. 3, Iss. 2, pp. 232-236.

20. Etminan S.R., Maini B.B., Chen Zh. Modeling the interface resistance in low soluble gaseous solvents-heavy oil systems. Fuel, 2013, vol. 105, pp. 672-687.

21. Speight J.G. Production of syngas, synfuel, bio-oils, and biogas from coal, biomass, and opportunity fuels. Fuel Flexible Energy Generation, 2016, no. 5, pp. 145-174.

Received: 12 November 2018.

\section{Information about the authors}

Valeriy F. Dyagilev, Cand. Sc., associate professor, Tyumen Industrial University. 